OPEN ACCESS

Edited by:

Shihui Yang,

Hubei University, China

Reviewed by:

Jinguang $\mathrm{Hu}$,

University of Calgary, Canada

Fubao Sun

Jiangnan University, China

*Correspondence:

Jianzhong Sun

jzsun1002@hotmail.com

Daochen Zhu

dczhucn@hotmail.com

†These authors have contributed equally to this work

Specialty section:

This article was submitted to

Synthetic Biology,

a section of the journal

Frontiers in Bioengineering and

Biotechnology

Received: 16 January 2020 Accepted: 29 May 2020

Published: 30 June 2020

Citation:

Murillo Morales G, Ali SS, Si H, Zhang W, Zhang R, Hosseini $K$, Sun J and Zhu D (2020) Acidic Versus

Alkaline Bacterial Degradation

of Lignin Through Engineered Strain

E. coli BL21(Lacc): Exploring

the Differences in Chemical Structure,

Morphology, and Degradation

Products.

Front. Bioeng. Biotechnol. 8:671.

doi: 10.3389/fbioe.2020.00671

\section{Acidic Versus Alkaline Bacterial Degradation of Lignin Through Engineered Strain E. coli BL21(Lacc): Exploring the Differences in Chemical Structure, Morphology, and Degradation Products}

\author{
Gabriel Murillo Morales ${ }^{1 \dagger}$, Sameh S. Ali ${ }^{1,3 t}$, Haibing Si ${ }^{1}$, Weimin Zhang ${ }^{2}$, \\ Rongxian Zhang ${ }^{4}$, Keyvan Hosseini ${ }^{5}$, Jianzhong Sun ${ }^{1 *}$ and Daochen Zhu ${ }^{1,2 *}$
}

\begin{abstract}
${ }^{1}$ Biofuels Institute, School of Environmental Science and Safety Engineering, Jiangsu University, Zheniiang, China, ${ }^{2}$ State Key Laboratory of Applied Microbiology Southern China, Guangdong Provincial Key Laboratory of Microbial Culture Collection and Application, Guangdong Open Laboratory of Applied Microbiology, Guangdong Institute of Microbiology, Guangdong Academy of Sciences, Guangzhou, China, ${ }^{3}$ Botany Department, Faculty of Science, Tanta University, Tanta, Egypt, ${ }^{4}$ School of Chemistry and Chemical Engineering, Jiangsu University, Zhenjiang, China, ${ }^{5}$ School of Public Affairs, University of Science and Technology of China, Hefei, China
\end{abstract}

There is increasing interest in research on lignin biodegradation compounds as potential building blocks in applications related to renewable products. More attention is necessary to evaluate the effects of the initial $\mathrm{pH}$ conditions during the bacterial degradation of lignin. In this study we performed experiments on lignin biodegradation under acidic and mild alkaline conditions. For acidic biodegradation, lignin was chemically pretreated with hydrogen peroxide. Alkaline biodegradation was achieved by developing the bacterial growth on Luria and Bertani medium with alkali lignin as the sole carbon source. The mutant strain Escherichia coli BL21(Lacc) was used to carry out lignin biodegradation over 10 days of incubation. Results demonstrated that under acidic conditions there was a predominance of aliphatic compounds of the $\mathrm{C}_{3}-\mathrm{C}_{4}$ type. Alkaline biodegradation was produced in the context of oxidative stress, with a greater abundance of aryl compounds. The final $\mathrm{pH}$ values of acidic and alkaline biodegradation of lignin were 2.53 and 7.90 , respectively. The results of the gas chromatography mass spectrometry analysis detected compounds such as crotonic acid, lactic acid and 3hydroxybutanoic acid for acidic conditions, with potential applications for adhesives and polymer precursors. Under alkaline conditions, detected compounds included 2phenylethanol and dehydroabietic acid, with potential applications for perfumery and anti tumor/anti-inflammatory medications. Size-exclusion chromatography analysis showed that the weight-average molecular weight of the alkaline biodegraded lignin increased by 6.75 -fold compared to the acidic method, resulting in a repolymerization of its molecular structure. Lignin repolymerization coincided with an increase in the relative abundance of dehydroabietic acid and isovanillyl alcohol, from 2.70 and $3.96 \%$ on day 
zero to 13.43 and $10.26 \%$ on 10 th day. The results of the Fourier-transformed Infrared spectroscopy detected the presence of $\mathrm{C}=\mathrm{O}$ bond and $\mathrm{OH}$ functional group associated with carboxylic acids in the acidic method. In the alkaline method there was a greater preponderance of signals related to skeletal aromatic structures, the amine functional group and the $\mathrm{C}-\mathrm{O}$ - bond. Lignin biodegradation products from E. coli BL21(LacC), under different initial pH conditions, demonstrated a promising potential to enlarge the spectrum of renewable products for biorefinery activities.

Keywords: lignin, E. coli BL21(Lacc), biodegradation compounds, acid/alkaline incubation, depolymerization/repolymerization

\section{INTRODUCTION}

Due to its abundance and complex polymeric structure, lignin represents a potential biomass resource for use in biorefinery activities (Saito et al., 2013). However, because of its intrinsic recalcitrane to depolymerization, its economical exploitation is still not feasible. Lignin's primary use is as energy source to produce heat and electricity for the paper and pulp industries (Chen and Wan, 2017; Van den Bosch et al., 2018). The microbiological partial degradation of lignin could represent a promising potential alternative to achieve a feasible production of renewable chemicals (Kosa and Ragauskas, 2013; Kohlstedt et al., 2018). Among the key advantages in the use of bacterial inoculation as approach to partial lignin biodegradation are its easy growth on a liquid medium, easy separation from the culture medium (facilitating recovery of the supernatants for analysis), and a flexible range of incubation temperatures. The whole cell bacterial degradation of lignin represents an opportunity to explore its potential as a source for renewable compounds. Taking advantage of the complex polymeric structure of lignin, could potentially produce a series of compounds of high interest for industries such as biofuels, bioplastics, food additives, pharmaceuticals, and others (Cline and Smith, 2017; Vinardell and Mitjans, 2017).

Laccase is among the most well-known ligninolytic enzymes under study. It is present in higher plants, fungi, and bacteria. Lignin partial biodegradation is achieved through redox reactions, via the oxidation of phenolic and nonphenolic structures and through the cleavage of some of the main lignin inter unit linkages such as $\beta-\mathrm{O}-4, \beta-\mathrm{O}-5, \beta-\beta$, etc. (Chatterjee and Saito, 2015), reducing molecular oxygen to water as a by-product. Researchers have demonstrated laccase's capacity to modify some functional groups of the lignin polymeric structure (Gianfreda et al., 1999; Hallac and Ragauskas, 2014; Constant et al., 2016; Zhu et al., 2018; Perez et al., 2019). Studies on lignin degradation through

Abbreviations: ABTS, 2,2'-azino-bis(3-ethylbenzothiazoline-6-sulfonic acid); BSTFA-TMCS, N,O-Bis(trimethylsilyl)trifluoro-acetamide with trimethylchlorosilane; FTIR, Fourier-transformed infrared spectroscopy; GC-MS, gas chromatography-mass spectrometry; SEC, size exclusion chromatography; HPLC, high-performance liquid chromatography; IPTG, isopropyl B-Dthiogalactopyranoside; LB medium, Luria and Bertani broth or also known as Lysogeny broth; $\mathrm{mM}$, milli molarity; $\mathrm{M}_{\mathrm{n}}$, number average molecular weight; $\mathrm{M}_{\mathrm{W}}$, weight average molecular weight; NaPSS, sodium polystyrene sulfonate; OD, optical density; OH, hydroxyl; PDI, polydispersity index; $\mathrm{pH}$, hydronium potential; SEM, scanning electron microscopy; TGA, thermogravimetric analysis; UV, ultraviolet radiation. bacterial laccase have especially focused their attention on the use of mediators, co-substrates, and optimal reaction temperature (Bourbonnais and Paice, 1990; Bourbonnais et al., 1997; Christopher et al., 2014). Additional studies have demonstrated that many microorganisms can display a series of specialized enzymes based on the availability of specific substrates (Kim et al., 2019). Nevertheless, to the best of our knowledge, studies assessing the partial degradation of lignin by microorganisms (in our particular case bacteria) under different $\mathrm{pH}$ conditions still remains obscure. Most studies on lignin biodegradation have paid little attention to the characterization of lignin degradation compounds and lignin chemical structure in the context of the $\mathrm{pH}$ incubation conditions.

Publications reporting on different lignin degradation compounds using whole-cell bacterial laccase strains under different $\mathrm{pH}$ conditions were recently reviewed. A study of lignin biodegradation using the bacterial strain Comamonas sp. B-9, isolated from eroded bamboo slips, performed the experiments on lignin mineral salt medium (KL-MSM) at an initial $\mathrm{pH}$ of 7.0 , at $30^{\circ} \mathrm{C}$, for 7 days. Some of the lignin degradation compounds found were isopropanol, 3-methyl-2-butanol and phenethyl alcohol (Chen et al., 2012). Another study on black liquor from rayon grade pulp paper industry reported its discoloring and detoxification with a potential bacterial consortium composed of Serratia marcescens, Citrobacter sp., and Klebsiella pneumonia. The experimental conditions involved placing a solution of $10 \%(\mathrm{v} / \mathrm{v})$ black liquor with $1 \%$ carbon and $0.5 \%$ nitrogen source in $100 \mathrm{~mL}$ volume in flasks of $250 \mathrm{~mL}$ for 8 days. After the first $24 \mathrm{~h}$, the initial $\mathrm{pH}$ started to drop from 8.0 to approximately 6.5. From there the $\mathrm{pH}$ progressively rose to approximately 7.5 on day 8 . Some of the lignin degradation compounds detected by gas chromatography/mass spectrometry (GC/MS) were carbamic acid, 1,2-benzenedicarboxylic acid and erythropentanoic acid (Chandra et al., 2011).

A study of directed biodegradation of Kraft lignin, without cosubstrates nor chemical pretreatment, was carried out with the bacterial strain Cupriavidus basilensis B-8. The incubation was tested along 7 days at $30^{\circ} \mathrm{C}$, but the $\mathrm{pH}$ was not reported. The study focused on the measurement and characterization of the production of polyhydroxyalkanoates (PHA's), omitting the characterization of other lignin degradation compounds. The total concentration of PHA's was $319.4 \mathrm{mg} \mathrm{L}^{-1}$, with (S)-3-hydroxy-butanoic acid, 3-hydroxy-butanoic acid, and 
3-hydroxybutyric acid in different percentages (Shi et al., 2017). Further studies reviewed reported the identification of value-added compounds from lignin biodegradation by bacteria (Duan et al., 2016; Suman et al., 2016; Zhu et al., 2017; Sapapporn et al., 2018; Shinoda et al., 2019; Yang et al., 2019). A thorough review of literature on lignin biodegradation identified the lack of research providing a systematic comparison of the lignin degradation in both sides of the $\mathrm{pH}$ spectrum using the same bacterial strain. Conducting such a study is necessary to advance research on lignin biodegradation by examining the resulting degradation compounds and the changes to lignin morphology, chemical structure, and molar mass accordingly.

To contribute to this gap in the research, our research group employed a recombined strain of Escherichia coli BL21, produced through an intracellular harboring of a laccase gene from the bacterial strain of Bacillus ligniniphilus L1, which was previously isolated from the sediments of the South China Sea (Zhu et al., 2014; Zhu et al., 2017). Preliminary results suggest that this mutant bacterial strain has potential to aid in the development of innovative strategies for lignin bacterial degradation. Based on this demonstrated potential, one scientific question must be answered: How do lignin chemical structure, morphology, and molar mass, and lignin degradation compounds produced from the partial degradation activity of the mutant strain E. coli BL21(Lacc) differ under acidic and mild alkaline consitions? To answer this question, two different samples of lignin were used: (1) alkali lignin without any chemical pretreatment and (2) alkali lignin which underwent a chemical pretreatment. The initial $\mathrm{pH}$ conditions of the samples trigger to drive the $\mathrm{pH}$ values of the bacterial growth media to suitable conditions along the incubation. The samples were analyzed for characterization including optical density $\left(\mathrm{OD}_{280}\right)$, measurements of $\mathrm{pH}$, morphology using scanning electron microscopy (SEM), changes in molar mass using size-exclusion chromatography (SEC), presence and identification of lignin degradation compounds using GC/MS and differences in the main functional groups using Fourier-transformed infrared spectroscopy (FTIR). Our results revealed remarkable differences in the lignin morphology, the chemical structure of some functional groups and the generation of biodegradation compounds. We performed experiments without the inoculation of the mutant strain E. coli BL21(Lacc) as controls. The results are described and discussed below.

\section{MATERIALS AND METHODS}

\section{Materials}

Reactants including alkali lignin (CAS number 8068-05-1), 2,2'-azino-bis(3-ethylbenzothiazoline-6-sulfonic acid) (ABTS), isopropyl $ß-\mathrm{D}$-thiogalactopyranoside (IPTG), kanamycin sulfate, 1,4-dioxane, pyridine, N,O-Bis(trimethylsilyl) trifluoro-acetamide with trimethylchlorosilane (BSTFATMCS), were purchased from Sigma-Aldrich, in St. Louis. $\mathrm{MO}$, United States. Nitrogen gas $\left(\mathrm{N}_{2}\right)$ was purchased from
Shanghai Chemical Industry Park $\mathrm{Pu}$ River specialty gases Co., Ltd. The rest of the chemicals described to prepare the different bacterial culture media were purchased from Sinopharm Chemical Reagent Co., Ltd. All the reactants were of analytical grade and used without further purification. The mutant strain E. coli BL21(Lacc) with a harbored laccase gene was recombinated at the Biofuels Institute of Jiangsu University.

\section{Pretreatment of Lignin With Hydrogen Peroxide}

A $500 \mathrm{~mL}$ solution of de-ionized water with alkali lignin at a concentration of $10 \mathrm{~g} \mathrm{~L}^{-1}$ was prepared. The $\mathrm{pH}$ of the black liquor was set at $3.0 \pm 0.1$ by adding $\mathrm{HCl}$ to the aqueous solution. Hydrogen peroxide $(30 \% \mathrm{v} / \mathrm{v})$ at a concentration of $141.12 \mathrm{mM}$ was added to the black liquor. A reactor (Weihai Zhengwei Machinery Equipment Co., Ltd., ZKCF-2L 1, China) submitted the substrates to anoxic conditions with dinitrogen gas at a temperature of $140 \pm 5.0^{\circ} \mathrm{C}$ for $20 \mathrm{~min}$ at a pressure of approximately $400 \mathrm{kPa}$. The black liquor was dried in hot air at a temperature (Jintan Medical Equipment Factory, DHG$9245 \mathrm{~A}$, China) between $60-80^{\circ} \mathrm{C}$ for 4 days. The chemically pretreated lignin was used for bacterial degradation under low $\mathrm{pH}$ conditions. For the mild alkaline method, lignin was used after overnight vacuum drying at $60^{\circ} \mathrm{C}$ in a heat drier (YiHeng Scientific Instrument Co., Ltd., BPZ-6033, China) to remove moisture.

\section{Preparation of Lignin Culture Medium for Acid and Mild Alkaline Degradation}

The initial growth of the mutant strain E. coli BL21(Lacc) took place on LB medium for approximately $18-24 \mathrm{~h}$. One milliliter of kanamycin sulfate solution $\left(0.01 \mathrm{~g} \mathrm{~mL}^{-1}\right)$ was added before the inoculation and $100 \mu \mathrm{L}$ of IPTG solution $(0.1 \mathrm{mM})$ after $12 \mathrm{~h}$ of inoculation. For the alkaline biodegradation method, ABTS mediator was added to the LB medium before sterilization. After $24 \mathrm{~h}$ of incubation, $10 \mathrm{~g} \mathrm{~L}^{-1}$ of alkali lignin (the lignin medium under alkaline conditions) were added.

For the acid method, the bacterial cells were precipitated from the $\mathrm{LB}$ culture medium via centrifugation at $10,000 \mathrm{rpm}$ for $20 \mathrm{~min}$. The pellets were transferred to the lignin medium under sterile conditions. The medium MM63 (used as lignin medium for acidic conditions) was prepared according to a method previously reported (Zhu et al., 2017). The medium MM63 consisted of $100 \mathrm{mM} \mathrm{KH}_{2} \mathrm{PO}_{4}, 75 \mathrm{mM} \mathrm{KOH}, 15 \mathrm{Mm}\left(\mathrm{NH}_{4}\right)_{2} \mathrm{SO}_{4}$, $1 \mathrm{mM} \mathrm{MgSO}_{4}$ and $3.9 \mu \mathrm{M} \mathrm{FeSO}$. Before sterilization, $1 \mathrm{~g}$ of lignin was added into $100 \mathrm{~mL}$ MM63 medium, along with $1 \mathrm{mM}$ of ABTS as mediator. After sterilization (Sanyo, MLS-3750, Japan), $2.5 \mathrm{~g}$ of glucose dissolved in $20 \mathrm{~mL}$ of deionized water were added into the culture medium and filtered by $0.2 \mu \mathrm{m}$ pore size filter for organic solutions. Next, $\mathrm{H}_{2} \mathrm{O}_{2}$ was added with a concentration of $0.50 \mathrm{mM}$ and $1 \mathrm{~mL}$ of kanamycin sulfate solution $\left(0.01 \mathrm{~g} \mathrm{~mL}^{-1}\right)$. For the mild alkaline method, lignin was used as a single carbon source without the addition of co-substrates. Before 
inoculations, the initial $\mathrm{pH}$ for LB and MM63 media were set at $7.0 \pm 0.10$.

After incubation, the bacterial cells were precipitated in a centrifuge (Beckman Advanti J-1, United States) at 12,000 rpm for $20 \mathrm{~min}$. Afterward the supernatants were boiled in a heater at $130^{\circ} \mathrm{C}$ for $20 \mathrm{~min}$. After cooling down the bacterial cells were precipitated again in the conditions described above. The supernatant was recovered, put into a refrigerator at $-20^{\circ} \mathrm{C}$ for $24 \mathrm{~h}$ and submitted to freeze drying (Christ Beta 1-8 LD plus, Germany) for 7 days and kept at cool temperature conditions before analysis. For the preparation of samples for GC/MS analysis, the supernatants were not freeze-dried.

\section{Optical Density Measures}

Aliquots of $0.5 \mathrm{~mL}$ were centrifuged at $12,000 \mathrm{rpm}$ for $5 \mathrm{~min}$ (Eppendorf, 5804R, Germany), boiled at $100^{\circ} \mathrm{C}$ for $20 \mathrm{~min}$ to inactivate and precipitate the bacterial cells and centrifuged again at the same rotational speed and time conditions. Before optical density readings, the samples were diluted in water at a factor of $1 / 1,000$. The wavelength for optical density measures was set at $280 \mathrm{~nm}\left(\mathrm{OD}_{280}\right)$ (Beckman DU 800 spectrophotometers, Beckman Coulter, Inc., United States). Deionized water was set as control. Readings were made in triplicate obtaining standard deviations smaller than or equal to 0.016 .

\section{pH Measures}

The initial and final $\mathrm{pH}$ readings of the lignin media, and the initial and final $\mathrm{pH}$ of the chemically pretreated lignin solution with $\mathrm{H}_{2} \mathrm{O}_{2}$ were conducted with a $\mathrm{pH}$ meter (INESA, PHS-25, China) with a precision of 0.01 . Intermediate readings were made with litmus paper. For litmus paper readings, a $\mathrm{pH}$ band of \pm 0.50 was added throughout the readings.

\section{Scanning Electron Microscopy}

Dried samples were mounted on small adhesive tapes, coated with a gold-palladium alloy, and examined with SEM using $1 \mu \mathrm{m}$ as reference scale (SEM, JSM-7800F, Japan).

\section{Gas Chromatography Mass Spectrometry}

The general procedures were prepared according to the method described by Zhu et al. (2017), with some modifications. For samples with bacterial activity at low $\mathrm{pH}$, the $\mathrm{pH}$ was adjusted to 2.0 using $5 \mathrm{M}$ of an aqueous solution of $\mathrm{HCl}$. For the samples with bacterial activity above $\mathrm{pH} 7.0$, there was no $\mathrm{pH}$ adjustment, to avoid inducing chemical modifications in the original compounds derived from the bacterial activity in the lignin medium and their controls. The samples were thoroughly mixed in twice their initial volume $(15 \mathrm{~mL})$ of ethyl acetate. The extraction mixture was collected and adjusted to approximately $1 \mathrm{~mL}$ via rotary evaporation at $37^{\circ} \mathrm{C}$ at vacuum, removing any presence of water with anhydrous $\mathrm{Na}_{2} \mathrm{SO}_{4}$. The samples were stored in small glass bottles. Afterward, the samples were evaporated under a stream of dinitrogen gas. The silylation reaction was developed by adding $100 \mu \mathrm{L}$ of 1,4-dioxane and
$10 \mu \mathrm{L}$ pyridine, followed by the addition of $50 \mu \mathrm{L}$ of (BSTFATMCS). The organic solution was frequently shaked in a water bath at $80^{\circ} \mathrm{C}$ for $45 \mathrm{~min}$. Before the final preparation of the samples for GC/MS analysis, the solutions were filtered using filter for organic solutions of $0.22 \mu \mathrm{m}$ pore size and transferred to clean bottles for sampling with a syringe of $1 \mathrm{~mL}$ volume. A volume of $1 \mu \mathrm{L}$ of silylated mixture was injected into the GC-MS equipment (Agilent Technologies, United States). The analytical column connected to the system was a PE-5MS capillary column $(20 \mathrm{~m} \times 0.18 \mathrm{~mm}$ internal diameter, $0.18 \mathrm{~mm}$ film thickness). Helium was used as a carrier gas with a flow rate of $1 \mathrm{~mL} \mathrm{~min}^{-1}$. The column temperature program was $50^{\circ} \mathrm{C}$ $(5 \mathrm{~min}) ; 50-280^{\circ} \mathrm{C}\left(10^{\circ} \mathrm{C} \mathrm{min}^{-1}\right.$, holding time of $\left.6 \mathrm{~min}\right)$. The transfer line and the ion source temperatures were maintained at 200 and $250^{\circ} \mathrm{C}$. A solvent delay of $3.0 \mathrm{~min}$ was selected. In the full-scan mode, electron ionization mass spectra in the range of $30-550(\mathrm{~m} / \mathrm{z})$ were recorded at an electron energy of $70 \mathrm{eV}$.

\section{Size-Exclusion Chromatography}

Molar mass analysis was performed in a Shimadzu Series HPLC system (Shimadzu, Japan), equipped with a column oven unit CTO-20AC, a liquid chromatograph unit LC-20AD, a UV/VIS detector SPD-20A and a degassing unit DGU-20A. A column TSKgel GMPWxl, (Tosoh Corporation) was used for the analysis, based on methacrylate copolymer, with a length of $30 \mathrm{~cm}$ and a diameter of $7.80 \mathrm{~mm}$, with an average copolymer particle size of $13 \mu \mathrm{m}$. The detection system was operated at a $280 \mathrm{~nm}$ wavelength, $50^{\circ} \mathrm{C}$ temperature and an $0.50 \mathrm{~mL} \mathrm{~min}{ }^{-1}$ eluent flow rate. The sample volume was $200 \mu \mathrm{L}$. The retention time was adjusted according to the results obtained by the universal calibration procedure. The software used for the determination of the molar mass was provided by Shimadzu LabSolutions GPC.

The universal calibration was made using five different types of NaPSS standards with different molecular weights - 1,690, $16,000,33,400,88,700$, and $234,800 \mathrm{~g} \mathrm{~mol}^{-1}$. The results were plotted with a logarithmic function of the molecular weight versus retention time. The solution used as eluent was $\mathrm{NaNO}_{3}$ at a concentration of $0.1 \mathrm{M}$ at pH 7.0 \pm 0.1 . The concentration of the dissolved samples, as well as the standards, was $3 \mathrm{mg} \mathrm{mL}^{-1}$ with a minimum liquid volume of $5 \mathrm{~mL}$ per sample. Before the analysis, the samples were filtered in a $0.22 \mu \mathrm{m}$ filter for organic solutions. The calculations for the different types of molecular weights $(\mathrm{Mw}, \mathrm{Mn})$ were based on the method previously reported (Andrianova et al., 2018).

\section{Fourier-Transformed Infrared Spectroscopy}

A Nicolet Nexus 470 spectrometer FT-IR with IR spectra between 400 and $4,000 \mathrm{~cm}^{-1}$ performed measures at room temperature, applying 10 scans in transmission mode, using $\mathrm{KBr}$ pellets of $0.1 \mathrm{~mm}$ thickness. The weight of the samples were of approximately $1 \mathrm{mg}$.

\section{Statistical Analysis}

A statistical correlation between optical density and $\mathrm{pH}$ values was evaluated. The analysis was made with IBM SPSS Statistics 

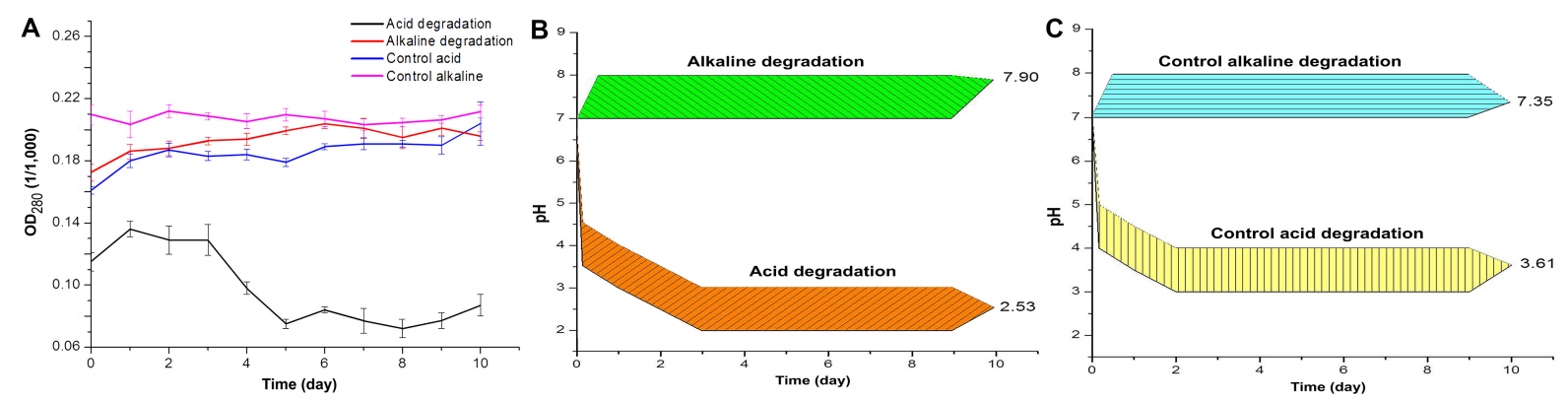

FIGURE 1 | (A) Optical density of acid and alkaline-biodegraded lignin and controls at $280 \mathrm{~nm}$. (B) pH measures of acid and alkaline-biodegraded lignin and (C) pH measures of controls. The range of the $\mathrm{pH}$ measures is \pm 0.50 .

Software version 22. The correlations were considered significant at the 0.05 level.

\section{RESULTS}

\section{Acidic and Alkaline Lignin Degradation With E. coli BL21(Lacc)}

The results of optical density and $\mathrm{pH}$ measures suggest a modification of lignin chemical structure throughout the incubation time. Figure 1A shows the optical density at the wavelength of $280 \mathrm{~nm}\left(\mathrm{OD}_{280}\right)$, which is related to the presence of phenolic groups in lignin (Sharma et al., 2019). For the acidic biodegradation sample, after day 3 the values of $\mathrm{OD}_{280}$ dropped, in an interval of 2 days, by $41.8 \%$. In the case of the alkaline biodegraded sample, there was a steady increase in the optical density from day zero to day 6 , for a total increase of $18.4 \%$. The results suggest that the main changes on lignin chemical structure occurred after day 5 for the sample under acid biodegradation and after day 6 for the alkaline sample. The optical density values for the control of acidic biodegradation of lignin (hereafter acidic control) were relatively stable, experiencing two increments in the intervals between the days 5 and 6 , and days 9 and 10 , in 5.29 and $6.86 \%$, respectively. In the control for alkaline biodegradation of lignin (hereafter alkaline control), the variation in the optical density was practically negligible. For the acid control, the initial variations in the optical density, particularly from day zero to day 1 , were primarily due to dissolution of lignin in the growth medium. The controls showed no significant changes in optical density.

Figure 1B shows the changes in $\mathrm{pH}$ for acidic and alkaline biodegradation of lignin while Figure 1C shows the changes in $\mathrm{pH}$ for the controls of acidic and alkaline biodegradation (hereafter acidic and alkaline controls). Represented in Figure 1B, there is a very fast drop in $\mathrm{pH}$ in the first hours of reaction for the acidic lignin biodegradation. This might be caused by a chemical equilibrium in the $\mathrm{pH}$ between the lignin medium and the chemically pretreated lignin with hydrogen peroxide. From the days zero to 3, a less intense drop in $\mathrm{pH}$ occurred. This may be related to the initial bacterial growth and glucose depletion on the lignin medium. After day 3 , the values of $\mathrm{pH}$ values remained relatively stable. The final $\mathrm{pH}$ value for the acidic biodegradation sample was 2.53. In previous literature, few fungal or bacterial strains containing laccase have shown a good capacity for degrading lignin or lignin model compounds under very low pH (Gianfreda et al., 1999; Margot et al., 2013). Our results, however, demonstrated the utility of bacterial laccase for modifying the chemically pretreated lignin under very low $\mathrm{pH}$, comparable with the optimal $\mathrm{pH}$ for ABTS activity in the oxidation of lignin model compounds ( $\mathrm{pH}$ 3.0) (Bourbonnais et al., 1997; Margot et al., 2013).

Figure 1B also shows a single $\mathrm{pH}$ band between 7.0 and 8.0 during the 10 days of reaction, suggesting that the ionic equilibrium is more limited in the alkaline range for this particular bacterial strain under the performed experimental conditions. The final $\mathrm{pH}$ value was 7.90. This result demonstrates the capacity of the mutant strain E. coli BL21(Lacc) to tolerate alkaline conditions to some extent. Our findings of lignin biodegradation in mild alkaline medium are comparable to other reports of lignin degradation and lignin model compounds using bacterial and fungal laccase in the alkaline side of the pH spectrum (Xu, 1997; Ruijssenaars and Hartmans, 2004). Figure 1C shows the $\mathrm{pH}$ values for the acidic and alkaline controls. Both results showed similar patterns to those of the $\mathrm{pH}$ values of the main samples in Figure 1B. The acidic control also used chemically pretreated lignin and $\mathrm{H}_{2} \mathrm{O}_{2}$ as co-substrate, maintaining a very similar equilibrium in $\mathrm{pH}$ values during the first hours of reaction in the lignin medium compared to the of acidic biodegradation sample of lignin along the 10 days of agitation. The final $\mathrm{pH}$ value for acidic control was 3.61, 1.08 higher than the value measured for the acidic biodegraded sample, reflecting a difference in the concentration of hydronium ions $\left[\left(\mathrm{H}_{3} \mathrm{O}^{+}\right)\right]$, favorable to the acidic biodegraded sample, of $2.7 \mathrm{mM}$. The $\mathrm{pH}$ values of the alkaline control fluctuated from 7.00 at the beginning of the reaction to 7.35 on day 10 . As the $\mathrm{pH}$ of alkali lignin in aqueous solution at a concentration of $10 \mathrm{~g} \mathrm{~L}^{-1}$ is higher than 8.0, it is reasonable to assume that the $\mathrm{pH}$ could reach an equilibrium value in the first hours of reaction even higher than 7.50, progressively decreasing during the reaction time. A similar reaction is expected in the alkaline biodegraded lignin sample. In conclusion, optical density and $\mathrm{pH}$ measurements showed differences between the biodegradation samples and their controls, suggesting a bacterial degradation of lignin during the 

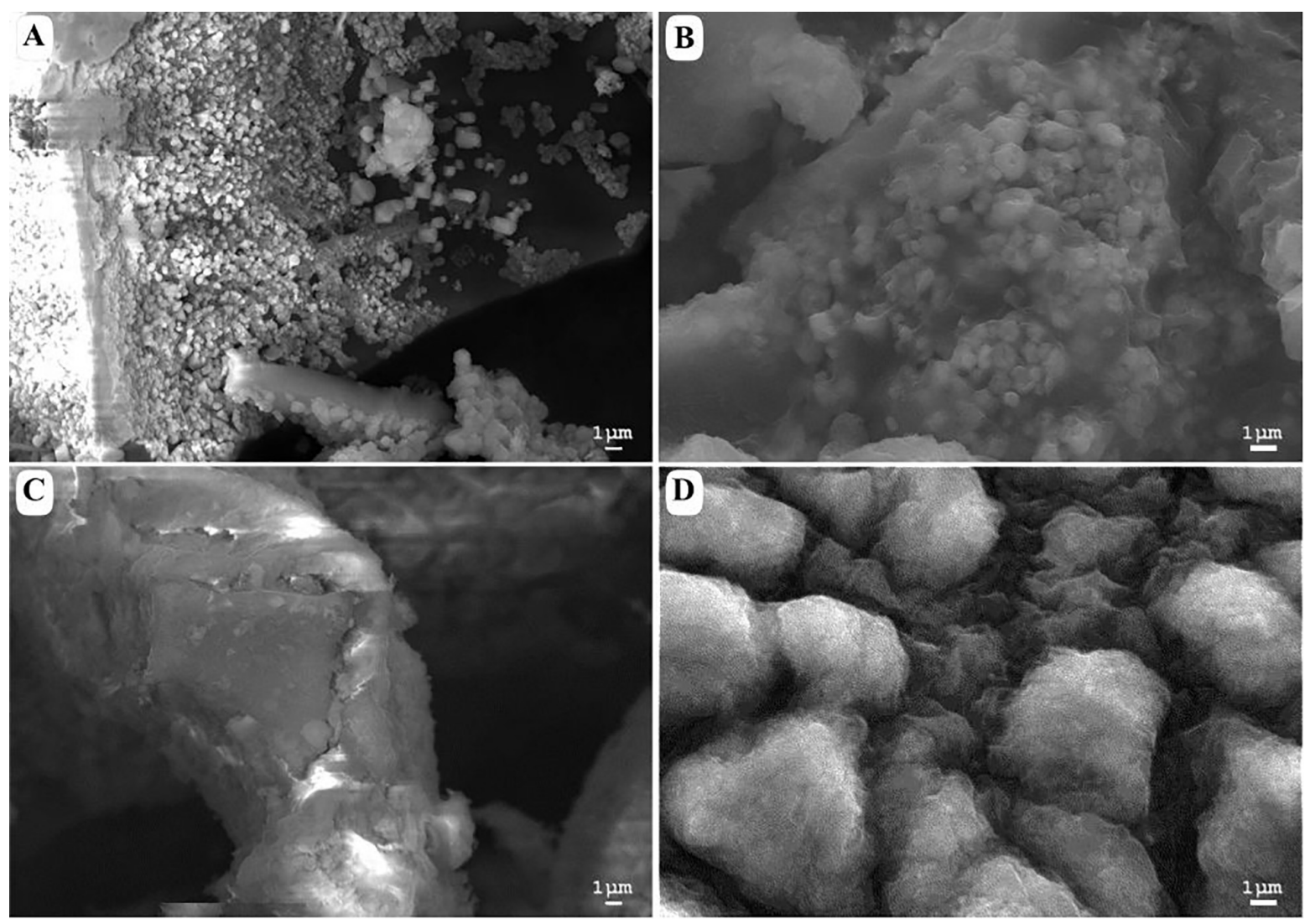

FIGURE 2 | Scanning electron microscopy images of (A) acid-biodegraded lignin,

(B) alkaline-biodegraded lignin, (C) control of acid biodegradation, and (D) control of alkaline biodegradation. Scale of reference of $1 \mu \mathrm{m}$.

10 days of reaction. This conclusion is further confirmed in the analysis below.

\section{Morphological Description}

Figure 2 shows a morphological comparison using SEM between the samples of acidic and alkaline biodegradation of lignin and their controls, with a scale of reference of $1 \mu \mathrm{m}$. Figure $2 \mathrm{~A}$ shows an acidic biodegradation sample of lignin with blocks in the background coated with a series of crystalline structures of minimum sizes of approximately $1 \mu \mathrm{m}$. Figure $2 \mathbf{B}$ shows a sample of alkaline biodegradation of lignin with blocks covered by non-crystalline moieties. The average size of the lignin moieties is also of approximately $1 \mu \mathrm{m}$. Figure $2 \mathrm{C}$ shows a sample of acidic control. Though the acidic control also used chemically pretreated lignin with $\mathrm{H}_{2} \mathrm{O}_{2}$, the scanned image demonstrates the existence of well-defined lignin particles approximately $10 \mu \mathrm{m}$ in size, without significant damage, and surrounded by foamy-like moieties. In the case of the alkaline control, an absence of clean lignin blocks appears in the background. The lignin moieties have an average size of approximately $5 \mu \mathrm{m}$. We conclude that the different $\mathrm{pH}$ conditions after lignin modification directly affected the final morphology of the samples. The differences are more notorious for the samples subjected to bacterial activity. Nevertheless, in the case of the alkaline control, there are important modifications on its morphology. In comparison with a typical SEM image of untreated alkali lignin, the acidic control sample suffered less morphological modifications (see Supplementary Figure S1).

\section{Identification of Lignin Biodegradation Compounds}

Gas chromatography/mass spectrometry analysis gave valuable insights to elucidate if there are differences in lignin degradation compounds under bacterial activity at different $\mathrm{pH}$ conditions. A summary of five targeted peaks for each method and their controls, indicating their relative abundance and potential applications, is shown in Table 1. The results of the GC/MS spectral analysis for acidic, alkaline lignin biodegradation, and their controls are shown in Figure 3. The full list of all the compounds - excluding the functional group related to the thioacetolysis reaction - is shown in Supplementary Table S1. It is important to mention that most of the lignin degradation compounds were derived from vanillin, which was identified in a previous GC/MS analysis of alkali lignin - without any chemical pretreatment or bio treatment -, and with a relative abundance of approximately $32 \%$ (unpublished).

In Table $\mathbf{1}$ it is the abundant presence of aliphatic compounds with the general structure $\mathrm{C}_{3}-\mathrm{C}_{4}$ namely carboxylic acids in 
TABLE 1 | Summary of main degradation compounds from lignin degradation by E. coli BL21(Lacc) and controls

\begin{tabular}{|c|c|c|c|c|c|c|c|c|c|}
\hline \multicolumn{5}{|c|}{ Acid biodegradation of lignin } & \multicolumn{5}{|c|}{ Alkaline biodegradation of lignin } \\
\hline Retention time & $\begin{array}{l}\text { Name } \\
\text { of compound }\end{array}$ & $\begin{array}{l}\text { Relative } \\
\text { abundance } \\
(\%)\end{array}$ & $\begin{array}{l}\text { Potential } \\
\text { applications }\end{array}$ & Image of compound & Retention time & $\begin{array}{l}\text { Name of } \\
\text { compound }\end{array}$ & $\begin{array}{l}\text { Relative } \\
\text { abundance }\end{array}$ & $\begin{array}{l}\text { Potential } \\
\text { applications }\end{array}$ & $\begin{array}{l}\text { Image of } \\
\text { compound }\end{array}$ \\
\hline 7.73 & Crotonic acid & 5.22 & $\begin{array}{l}\text { Precursor for paints } \\
\text { and adhesives }\end{array}$ & & 13.38 & 2-phenylethanol & 3.75 & $\begin{array}{l}\text { Ingredient in flavors } \\
\text { and fragances }\end{array}$ & \\
\hline 10.53 & DL-lactic acid & 11.28 & $\begin{array}{l}\text { Polymer precursor, } \\
\text { descaler, anti bacterial } \\
\text { agent }\end{array}$ & & 16.38 & $1 \mathrm{H}$-Indole & 32.00 & Bacterial signal & \\
\hline 12.33 & $\begin{array}{l}\text { 3-hydroxy } \\
\text { butanoic acid }\end{array}$ & 3.32 & Copolyester & & 18.80 & Isovanillyl alcohol & 10.26 & Ingredient in flavors & \\
\hline 20.23 & Vanillic acid & 4.83 & Flavoring agent & & 23.10 & Hexadecanoic acid & 4.33 & $\begin{array}{l}\text { Substrate for } \\
\text { biofuels }\end{array}$ & \\
\hline 20.82 & $\begin{array}{l}\text { Protocatechuic } \\
\text { acid }\end{array}$ & 9.67 & $\begin{array}{l}\text { Antioxidant/anti } \\
\text { inflammatory }\end{array}$ & & 26.17 & Dehydroabietic acid & 13.43 & $\begin{array}{l}\text { Anti microbial, anti } \\
\text { tumor, anti } \\
\text { inflammatory }\end{array}$ & \\
\hline \multicolumn{5}{|c|}{ Control acid biodegradation of lignin } & \multicolumn{5}{|c|}{ Control alkaline biodegradation of lignin } \\
\hline 7.73 & Crotonic acid & 6.31 & $\begin{array}{l}\text { Precursor for paints } \\
\text { and adhesives }\end{array}$ & & 7.73 & Crotonic acid & 5.46 & $\begin{array}{l}\text { Precursor for paints } \\
\text { and adhesives }\end{array}$ & \\
\hline 10.55 & $\begin{array}{l}\text { Propylene } \\
\text { glycol }\end{array}$ & 16.48 & $\begin{array}{l}\text { Thermoplastics, anti } \\
\text { freeze, cosmetics }\end{array}$ & & 8.09 & Ethanamine & 5.91 & $\begin{array}{l}\text { Co-substrate in } \\
\text { medical } \\
\text { applications }\end{array}$ & \\
\hline 14.68 & Succinic acid & 7.10 & $\begin{array}{l}\text { Metabolic intermediate, } \\
\text { platform for polymers }\end{array}$ & & 18.60 & Apocynin & 8.53 & $\begin{array}{l}\text { Anti inflammatory } \\
\text { agent }\end{array}$ & \\
\hline 20.23 & Vanillic acid & 4.34 & Flavoring agent & & 20.23 & Vanillic acid & 6.11 & Flavoring agent & \\
\hline 20.82 & $\begin{array}{l}\text { Protocatechuic } \\
\text { acid }\end{array}$ & 7.88 & $\begin{array}{l}\text { Antioxidant/anti } \\
\text { inflammatory }\end{array}$ & & 26.17 & Dehydroabietic acid & 4.47 & $\begin{array}{l}\text { Anti microbial, anti } \\
\text { tumor, anti } \\
\text { inflammatory }\end{array}$ & \\
\hline
\end{tabular}



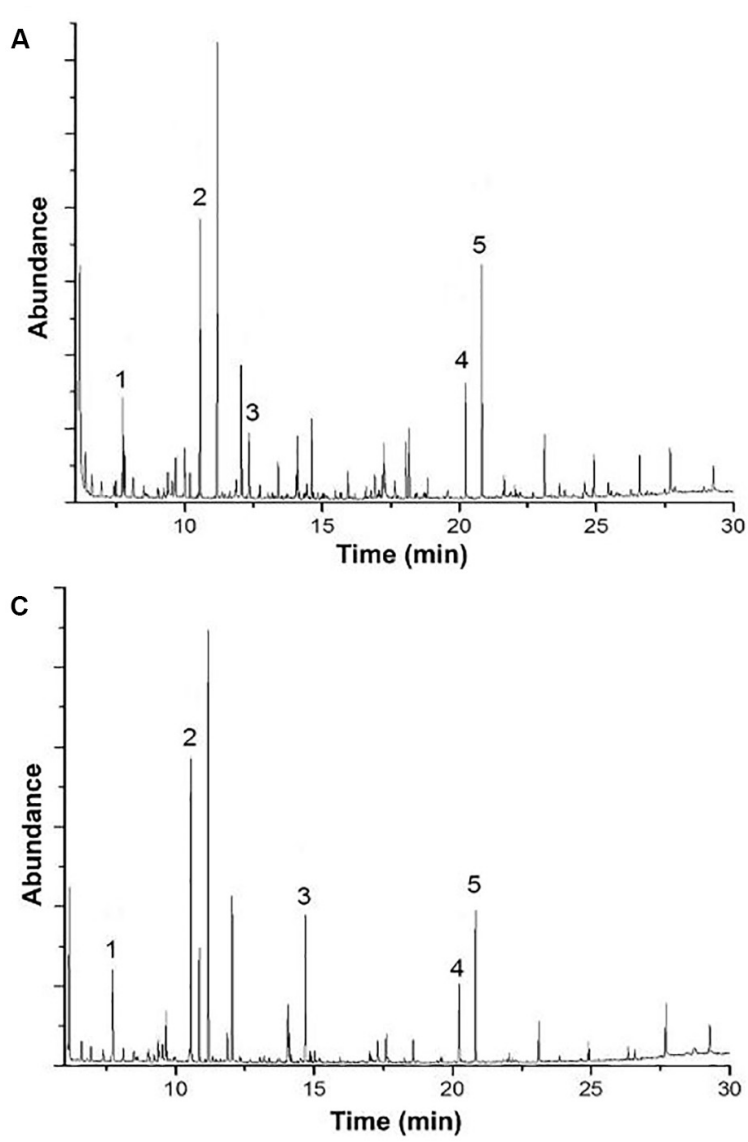
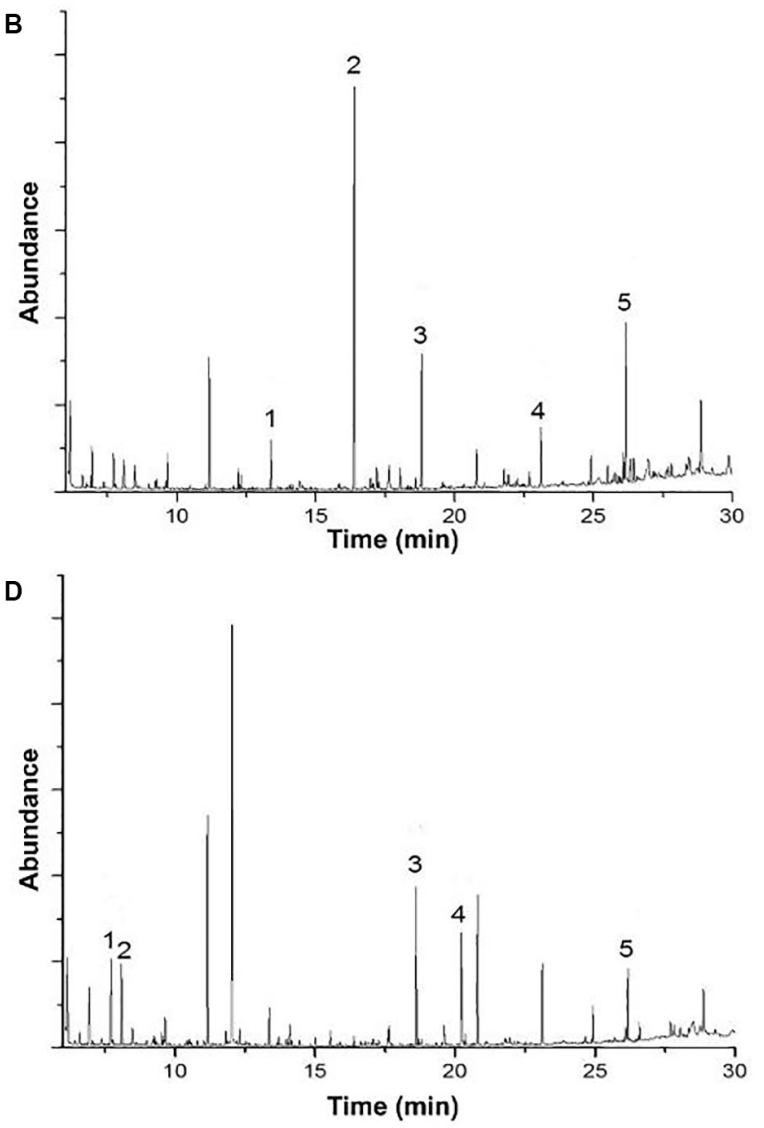

FIGURE 3 | Gas chromatography-mass spectrometry analysis of (A) acid biodegradation of lignin, (B) alkaline biodegradation of lignin, (C) control for acid biodegradation, and (D) control for alkaline biodegradation.

the acidic biodegradation sample, such as crotonic acid (\#1), lactic acid (\#2), and 3-hydroxybutanoic acid (\#3), with relative abundances of $5.22,11.28$, and $3.32 \%$, respectively. The shortchain carboxylic acids have potential applications as substrates for polymers and chemical precursors for paints, adhesives and other compounds (Doi et al., 1988; Rajan et al., 2014; Yang et al., 2018; Hack et al., 2019). Furthermore, two compounds with aromatic structures were also identified: vanillic acid (\#4) and protocatechuic acid (\#5), with relative abundances of 4.82 and $9.67 \%$. These compounds are associated with the bacterial metabolism of vanillin. Vanillic acid was detected at the retention time of $20.228 \mathrm{~min}$ (see Figures 3A,C). Recently, researchers have reported on the use of vanillic acid as building block for copolymers (Gioia et al., 2018). Protocatechuic acid is wellknown for its antioxidant capacity (Xi et al., 2016), and thus has potential for use in medicine/pharmaceutics.

The five targeted peaks of the alkaline biodegradation sample are 2-phenylethanol (\#1), 1H-indole (\#2), isovanillyl alcohol (\#3), hexadecanoic acid (\#4), and dehydroabietic acid (\#5). The relative abundances of each compound were $3.75,32.00,10.26,4.33$, and $13.44 \%$, respectively. 2-phenylethanol is used as an ingredient for flavors and perfumery for its rose-like aroma (Sendovski et al., 2010). $1 \mathrm{H}$-indole is a molecule that acts as an important bio signal which is produced from some bacterial strains to regulate the transition from the exponential to the stationary phase. It is also related to a stress response and promotes resistance to a range of antibiotics and toxins through physical export and oxidativestress protective mechanisms (Lee et al., 2010). Isovanillyl alcohol is an isovanilloid associated with vanillin, which is used as an ingredient in the food industry. Hexadecanoic acid is the only carboxylic acid on the list. It is used as a substrate for biofuels synthesis (Janßen and Steinbüchel, 2014). Dehydroabietic acid is found in resins or extracts of conifers and has being the subject of research for its anti-microbial, anti-tumor and anti-inflammatory properties (González, 2015; Vahermo et al., 2016).

The acidic and alkaline controls showed some similarities and differences compared to the samples under the bacterial activity of E. coli BL21(Lacc). The five compounds identified in Table 1 for the acidic control were crotonic acid (\#1), propylene glycol (\#2), succinic acid (\#3), vanillic acid (\#4), and protocatechuic acid (\#5). The relative abundances represented 6.36, 16.48, $7.10,4.34$, and $7.88 \%$, respectively. Compared with the lignin's acidic biodegradation sample, it is notable that in the acidic control the compounds in common also have similar relative abundances. For crotonic acid and vanillic acid, this suggests a limited metabolism of those compounds by the mutant bacterial 
strain. The differences of the lignin degradation compounds between the acidic biodegradation sample and its control are also evident. Some of the most remarkable differences rely on the presence of propylene glycol and succinic acid. On the other hand, the compounds in the acidic biodegradation sample are present in higher amounts, making up between 2.0 and $3.0 \%$. The compounds found only in the acidic biodegradation sample include lactic acid, almost in the same retention time than propylene glycol (10.536 versus $10.55 \mathrm{~min})$, glycerol (14.101 $\mathrm{min})$, and adipic acid (17.235 $\mathrm{min})$, among others (see Supporting Material 2). These results reflect an intense metabolic activity in the chemically modified lignin, which resulted in the degradation of the initially abundant aromatic compounds, suggesting that the addition of glucose as co-substrate, in synergy with the mutant bacterial strain could propitiate a more complex biological effects on lignin.

The alkaline control also exhibited some similarities and differences with the compounds found in the sample of alkaline biodegradation sample. For the alkaline control, are worth mentioning crotonic acid (\#1), ethanamine (\#2), apocynin (\#3), vanillic acid (\#4), and dehydroabietic acid (\#5). Their relative abundances represented 5.46, 5.91, 8.53, 6.11, and $4.47 \%$. From this list two compounds were also present in the acidic control: crotonic acid and vanillic acid. The differences between the products of the alkaline biodegradation sample were also notable. In the alkaline biodegradation sample, there was a preponderance of three compounds: $1 \mathrm{H}$-indole, isovanillyl alcohol, and dehydroabietic acid. Dehydroabietic acid was also present in the alkaline control, but in the case of the alkaline biodegradation sample, the relative abundance was almost threefold higher. As expected, $1 \mathrm{H}$-indole was not identified in the alkaline control sample, confirming the absence of bacterial activity. $1 \mathrm{H}$-indole is produced as a bio signal for oxidative stress in the bacterial growth medium. Besides the high concentration of $1 \mathrm{H}$-indole, the simultaneous absence of apocynin in the sample under biodegradation confirms the environment of oxidative the bacterial mutant strain was under during lignin oxidation in mild alkaline conditions (Stefanska and Pawliczak, 2008).

Contrasting with the large amount of lignin degradation compounds in the acidic biodegradation sample, the GC/MS analysis detected lower amounts of lignin degradation compounds in the alkaline biodegradation sample (see Figures $\mathbf{3 A}, \mathbf{B}$ ). In Table $\mathbf{1}$, the differences in their chemical structure are notable. The five targeted peaks of the alkaline biodegradation sample comprised $63.77 \%$ of the total detection by GC/MS, nearly double the amount measured in the acid biodegradation sample (32.81\%). Most of the relative abundances in the alkaline method came from compounds containing at least one aromatic structure. Some of them originated from lignin degradation by E. coli BL 21(Lacc), and one was produced as a bio signal ( $1 \mathrm{H}$-indole). A carboxylic acid molecule is present at the retention time of $23.107 \mathrm{~min}$ (hexadecanoic acid), which was also detected in the acidic method, in both cases a small amount. The presence of this compound in all the samples and their controls (see Supplementary Table S1) requires further study.

Due to their high relative abundances, particular attention was paid to $1 \mathrm{H}$-indole and dehydroabietic acid. Samples were analyzed using GC/MS on the days $0,3,7$, and 10 to track the evolution of their relative abundances (see Supplementary Table S2). After several hours of the addition of lignin on day zero, the relative abundance of $1 \mathrm{H}$-indole reached $19.71 \%$. It is likely that $1 \mathrm{H}$-indole was already produced before the addition of lignin due to the previous addition of tryptone for the preparation of the LB medium for the initial bacterial growth. On day 7 , its abundance peaked at $56.52 \%$, and then decreased to $32.00 \%$ on day 10 . The initial $\mathrm{pH}$ conditions of the alkaline lignin medium could trigger high production of $1 \mathrm{H}$-indole from resistant cells as an assistance to sensitive cells for their survival in the initial incubation conditions. The relative abundance of dehydroabietic acid on day zero was $2.70 \%$, progressively increasing its value during the incubation time, reaching its maximum value of $13.44 \%$ on day 10 . Interestingly, in the case of isovanillyl alcohol, there was also an increase in its relative abundance, starting with $3.96 \%$ on day 0 , reaching a maximum value of $12.10 \%$ on day 7 , and ending on day 10 with $10.26 \%$. All of these compounds have a similar response in their relative abundances throughout the bacterial activity.

In conclusion, most of the lignin degradation compounds produced by the bacterial mutant strain activity of $E$. coli BL21(Lacc) could be conditioned by the evolution of the $\mathrm{pH}$ values during lignin biodegradation. The main trend was the production of carboxylic acids at low $\mathrm{pH}$ values, and a series of diverse aryl compounds in the alkaline side with an increase for some in their relative abundance under oxidative stress conditions after 7 days of reaction.

\section{Statistical Analysis}

The Shapirov-Wilk test was initially performed to verify whether the optical density and $\mathrm{pH}$ values fit a normal probability distribution. The probability values ( $p$-values) obtained from the Shapirov-Wilk test in the case of alkaline biodegradation of lignin experiment were greater than 0.05 , which implied that the results were normally distributed. The correlation between the optical density and the $\mathrm{PH}$ values obtained throughout 11 observations for the experiment for alkaline biodegradation was equal to 0.829 , indicating a high significant positive correlation (see Table 2).

The $p$-values obtained from Shapirov-Wilk test for the acidic biodegradation sample of lignin were smaller than 0.05 , which indicated that the results did not follow a normal distribution. Thus, we performed the non-parametric Spearman correlation coefficient test for the 11 observations. The test revealed a high significant positive correlation of 0.726 (see Table 2). In the case of the acidic control sample, our results did not follow the normal distribution. Thus, we performed the non-parametric Spearman correlation coefficient test. The test revealed a high significant negative correlation of 0.852 . For the results obtained from the of alkaline control sample, there was no significant correlation. The results of this analysis are shown in Table 2.

We conclude that for acidic and mild alkaline degradation of lignin using the mutant strain E. coli BL21(Lacc) there was a highly significant positive correlation between the values of $\mathrm{OD}_{280}$ and $\mathrm{pH}$ throughout the 10 days of reaction. 
TABLE 2 | Statistical correlation between optical density and pH for acid and alkaline biodegradation of lignin and controls.

\begin{tabular}{|c|c|c|c|}
\hline Sample & Statistical correlation & Correlation test & Significance level \\
\hline Acid biodegradation of lignin & 0.726 & Parametric Pearson & 0.01 \\
\hline Control acid & -0.852 & Parametric Pearson & 0.01 \\
\hline Alkaline biodegradation of lignin & 0.829 & Non-parametric Spearman & 0.01 \\
\hline Control alkaline & -0.227 & Parametric Pearson & No significance \\
\hline
\end{tabular}

A

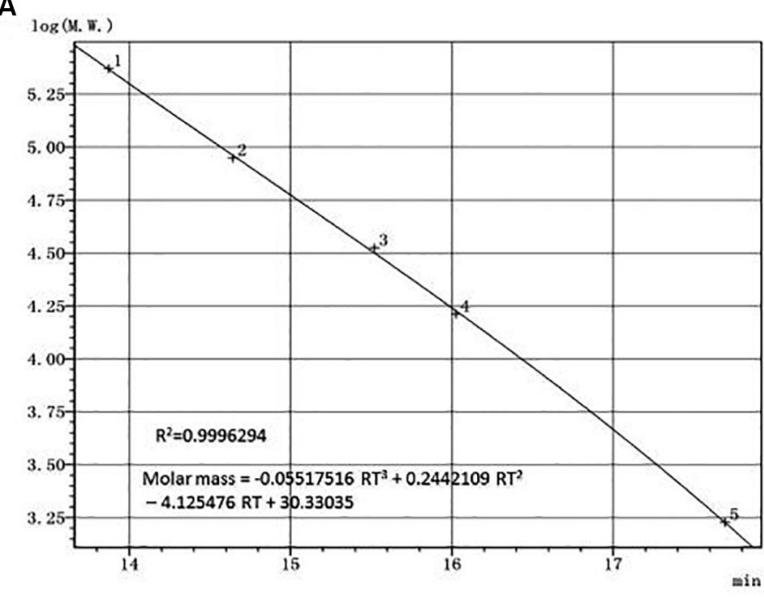

B

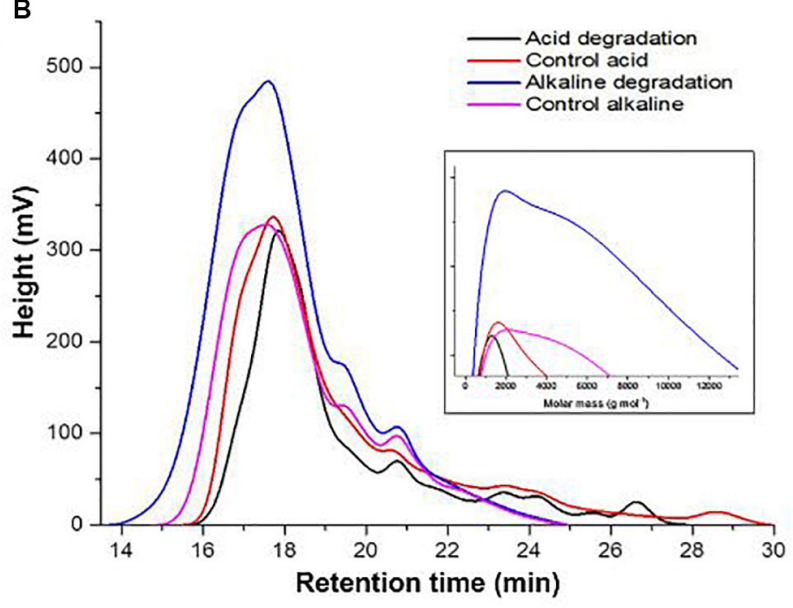

FIGURE 4 | Size exclusion chromatography analysis. (A) Universal calibration, (B) curves of acid, alkaline biodegradation of lignin, and controls. From the equation of the universal calibration, "RT" means "retention time."

\section{Molar Mass Analysis}

Molar mass represents an important parameter which reflects quantitative changes on a quantitative basis. The universal calibration curve in Figure $4 \mathrm{~A}$ shows a very high value in the coefficient of determination, allowing to use its equation for the estimations of $M_{n}$ and $M_{w}$. Figure $4 B$ shows the spectral curves for the samples of acidic and alkaline biodegradation of lignin and their controls, indicating the retention time in the abscissa of the main chart. The augmentated chart of the curves of molar mass shows the equivalent values of the molar mass in the abscissa, in $\mathrm{g} \mathrm{mol}^{-1}$ (from 0 to $13,000 \mathrm{~g} \mathrm{~mol}^{-1}$ ). The main chart notes that the curves of the molar mass of acidic biodegradation of lignin and its control have broader late eluting portions (Chatterjee and Saito, 2015), evidence of ionic adsorptions between the lower mola2r mass fractions of lignin and the GPC column particles. In contrast, the of alkaline biodegradation samples of lignin and the alkaline control showed more compact configurations. For the alkaline biodegradation sample, its peak was found in a region of higher molar mass. A similar result was found for the curve of the molar mass of the alkaline control, but more moderate.

Table 3 shows the values of the number-average $\left(M_{n}\right)$ and weight-average $\left(M_{W}\right)$ molar mass of the lignin samples. The sample submitted to alkaline biodegradation underwent a 6.75-fold and 3.45-fold increase in its $M_{w}$ and $M_{n}$ values compared to the biodegraded sample in acidic conditions (32,325 and 7,095 $\mathrm{g} \mathrm{mol}^{-1}$ for alkaline biodegradation of lignin versus 11,254 and $2,054 \mathrm{~g} \mathrm{~mol}^{-1}$ for acidic biodegradation of lignin), and for alkaline biodegradation, the polydispersity index (PDI) was 4.55, a 1.96-fold increase compared to the PDI value of 2.32 for the acidic biodegradation of lignin (Chatterjee and Saito, 2015). It can be inferred that a repolymerization occurred on the molecular structure of the sample of alkaline biodegradation after the incubation time. This might be caused due to the degradation of the lightest molar mass lignin fractions in combination by complex chemical interactions during the bacterial activity of E. coli BL21(Lacc), viz., changes in polarity of lignin blocks, rearrangement of non-covalent bonds, etc. Our findings on the increase of lignin's molar mass are in agreement with previously reported studies (Nugroho Prasetyo et al., 2010; Moya et al., 2011).

The acidic control showed slight differences compared to its corresponding biodegraded sample, reaching higher values on its $M_{n}$, and $M_{w}$ values by 25 and $33 \%$, respectively. The PDI value of the acidic biodegraded sample was higher than its control by $5.9 \%$. Interestingly, in the case of the alkaline control there was an increase in the values of $M_{n}$, and $\mathrm{M}_{\mathrm{w}}$ compared to the acidic control. The alkaline control experienced increments in the $M_{n}$, and $M_{w}$ values by 59 and $87 \%$, respectively. From these results we conclude that a depolymerization occurred in the acidic biodegradation sample of lignin where ring-opening reactions could occur, generating a series of short-chain aliphatic compounds with many carboxylic 
acids among them. On the other hand, the alkaline conditions could trigger changes in the concentration of the main lignin monomers, which could be attributed to the interactions between reactive functional groups of lignin. This would lead to the rearrangement and reconfiguration of lignin's overall chemical structure after 10 days of shaking, producing a stronger repolymerization on the lignin degraded sample and a moderate repolymerization on its control.

In order to elucidate lignin repolymerization during the alkaline incubation, we also measured the molar mass on days 1 and 5. Table 4 shows the results. From days $1-5$, there was a twofold increase approximately in the values of $M_{n}$ and $M_{w}$ relative to the first day. From days 5 to 10 , the increase ratio became larger, in the order by almost fourfold relative to day 5 . The PDI values also changed over time, increasing from 2.78 on day 1 , to 3.50 on day 5 , and to 4.56 on day 10 . These results suggest that the alkaline biodegradation of lignin could exert an important influence over the changes in the molar mass of lignin, particularly after the fifth day. Our results suggest that the changes in the molar mass of alkaline biodegradation of lignin could be a consequence of major changes in the lignin's polymeric structure. The changes in the relative abundance of some compounds reinforces this possibility. The increase of the relative abundance of dehydroabietic acid (molecular weight $=300.4 \mathrm{~g} \mathrm{~mol}^{-1}$ ) on days $0,3,7$, and 10 , determined by GC/MS analysis, provides a clear example. The abundance of this metabolite was $2.7,5.23,13.14$, and $13.44 \%$, respectively (see Supplementary Table S2). A similar phenomenon was observed with isovanillyl alcohol.

\section{Structural Characterization}

The FTIR analysis method provided insights for a qualitative evaluation of the chemical structure of alkaline and acidic biodegraded lignins and their controls. The analysis confirmed the presence of guaiacyl $(\mathrm{G})$ and syringyl (S) lignins (Gall et al., 2014). Some differences in the presence of functional groups among the lignin preparations were found and the results are shown in Figure 5. Figure 5A displays the overall FTIR spectra, Figure 5B shows more details from the wave numbers 450 to $1,300 \mathrm{~cm}^{-1}$, while Figure 5C shows from 1,300 to $1,800 \mathrm{~cm}^{-1}$ and Figure 5D shows from 2,250 to $3,700 \mathrm{~cm}^{-1}$, respectively.

In Figure 5B, at the wave number of $1,228 \mathrm{~cm}^{-1}$, there is a band displayed for the alkaline biodegradation sample and its control, which depicts the stretching of the $\mathrm{C}-\mathrm{O}-\mathrm{C}$ bond, providing important evidence of the stronger presence of aryl ether linkages, viz., $\beta-\mathrm{O}-4^{\prime}$ bond (Yang et al., 2007). In-plane deformations of $\mathrm{C}-\mathrm{H}$ bonds in $\mathrm{G}$ type lignins (in aromatic structures and aliphatic moieties) are evidenced at wave numbers 1,147 and $883 \mathrm{~cm}^{-1}$, while the band at $995 \mathrm{~cm}^{-1}$ belongs to the deformations out of plane in the $-\mathrm{CH}=\mathrm{CH}-$ group (Faix, 1991; Sun et al., 2003). The band at $1,080 \mathrm{~cm}^{-1}$ is only present in the alkaline samples, corresponding to the stretching of the $\mathrm{C}-\mathrm{O}$ bond, and reaffirming the previously described at the peak at $1,228 \mathrm{~cm}^{-1}$ (Sun et al., 2003). The peak at $620 \mathrm{~cm}^{-1}$ possibly describes the presence of a $\mathrm{S}-\mathrm{O}$ bond, becoming particularly accentuated in the cases of acidic biodegradation of lignin and its control (Nugroho Prasetyo et al., 2010).
The band identified at the wave number 1,716 in Figure 5C is related to the $\mathrm{C}=\mathrm{O}$ stretch for carboxylic acids. This result fits with the band assigned to the $\mathrm{O}-\mathrm{H}$ bond for the acidic degradation sample and its control (El Mansouri and Salvadó, 2007; Faix, 1991). The alkaline samples showed a signal at the wave number of $1,633 \mathrm{~cm}^{-1}$, assigned to the stretching of the $\mathrm{C}=\mathrm{C}$ bonds of benzene rings in the IR spectra (Yang et al., 2007). Although is not confirmed, we surmise this could be associated with the repolymerization in alkaline conditions of the lignin biodegraded sample and its control. In contrast, at $1,602 \mathrm{~cm}^{-1}$, all the samples displayed aromatic skeletal vibrations in the $\mathrm{C}-\mathrm{O}$ bonds. This could be related to ether bonds, where the alkaline samples and the acidic control showed higher intensities, evidence of the preservation of ether linkages among aromatic structures (Faix, 1991; Sun et al., 2003; Gillgren et al., 2017). At $1,513 \mathrm{~cm}^{-1}$ all the samples had a peak, corresponding to aromatic skeletal vibrations, G > S (Faix, 1991; Gordobil et al., 2016; Yu et al., 2019). The $\mathrm{C}-\mathrm{H}$ stretch identified at 1,446; 1,423 and $1,404 \mathrm{~cm}^{-1}$ are related to the $\mathrm{C}-\mathrm{H}$ bonds in Figure 5D at the wave numbers $2,958,2,875$, and $2,852 \mathrm{~cm}^{-1}$, respectively (Wade, 2013).

As reported in Figure 5D, all the lignin samples showed a broad response in the absorption band related to the $\mathrm{O}-\mathrm{H}$ bond for aromatic structures at $3,432 \mathrm{~cm}^{-1}$ (Cheng et al., 2016), with the exception of the acidic control, which was identified at $3,500 \mathrm{~cm}^{-1}$. The acidic biodegradation sample and its control showed a second absorption band between the wave numbers 3,240 and $3,149 \mathrm{~cm}^{-1}$. This band is assigned to the stretching of the $\mathrm{O}-\mathrm{H}$ bond of carboxylic acids. For the biodegradation of lignin under low $\mathrm{pH}$ conditions, based on GC/MS data, the relative abundance of the carboxylic acids had an important share in the total detection of all the compounds, confirming the assignment of the wave number to this chemical bond (Yang et al., 2007). The alkaline samples of lignin displayed a signal at $3,070 \mathrm{~cm}^{-1}$, which can be attributed to the $\mathrm{N}-\mathrm{H}$ bond (Wade, 2013). We speculate that the band at $3,039 \mathrm{~cm}^{-1}$, particularly strong in the sample of the acid control, could belong to a stronger presence of the stretching of the hybridized $\mathrm{sp}^{2} \mathrm{C}-$ $\mathrm{H}$ bond (Wade, 2013). The signals at the wave numbers 2,958, 2,875 and $2,852 \mathrm{~cm}^{-1}$ are related to the asymmetric vibrations

TABLE 3 | Molar mass characterization of lignin samples.

\begin{tabular}{lccc}
\hline Sample & $\mathbf{M}_{\mathbf{w}}$ & $\mathbf{M}_{\mathbf{n}}$ & PDI \\
\hline Alkaline biodegradation of lignin & 32,325 & 7,095 & 4.55 \\
Acid biodegradation of lignin & 4,782 & 2,054 & 2.32 \\
Control acid & 5,996 & 2,741 & 2.19 \\
Control alkaline & 11,254 & 4,362 & 2.58 \\
\hline
\end{tabular}

TABLE 4 | Change in molar mass for alkaline biodegradation of lignin.

\begin{tabular}{lccc}
\hline Day & Mn & Mw & PDI \\
\hline 1 & 2,083 & 5,798 & 2.78 \\
5 & 2,767 & 9,671 & 3.50 \\
10 & 7,095 & 32,325 & 4.56
\end{tabular}



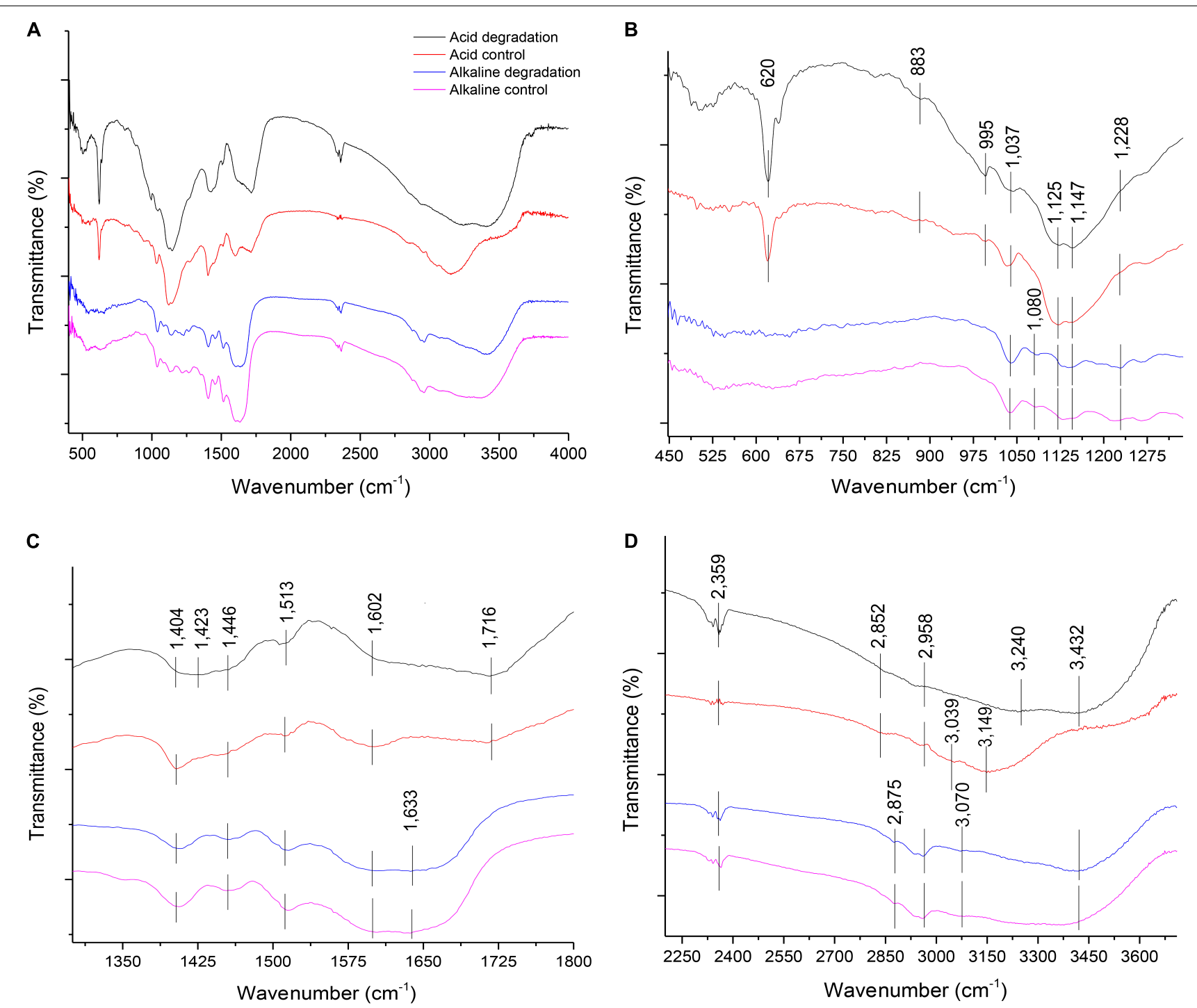

FIGURE 5 | (A) Overall FTIR spectra of acid and alkaline biodegradation of lignin and controls; (B) spectra from wave numbers $450-1,300 \mathrm{~cm}^{-1}$; (C) $1,300-$ $1,800 \mathrm{~cm}^{-1} ;$ (D) $2,250-3,700 \mathrm{~cm}^{-1}$.

and stretching of $\mathrm{sp}^{3}$ hybridization of $\mathrm{C}-\mathrm{H}$ bonds, particularly $\mathrm{CH}_{3}$ and $-\mathrm{CH}_{2}$ - groups, associated to aliphatic and aromatic structures (El Mansouri and Salvadó, 2007; Wade, 2013; Yang et al., 2007; Reyes-Rivera and Terrazas, 2017). The band at $2,359 \mathrm{~cm}^{-1}$ was assigned to the presence of the nitrile functional group $(-\mathrm{C} \equiv \mathrm{N})$, which was confirmed in the results of GC/MS analysis (see Supplementary Table S1; Wade, 2013).

\section{DISCUSSION}

In this study, alkali lignin was submitted to partial biodegradation by the bacterial mutant strain E. coli BL21(Lacc) under acidic and mild alkaline conditions for 10 days. The final outcomes from those treatments were remarkably different in terms of optical density response,
$\mathrm{pH}$ evolution, morphology, detection of lignin degradation compounds, presence of functional groups, and changes in the molar mass.

The signals detected by the optical density measures at $280 \mathrm{~nm}$, which indicates the presence of aromatic structures in lignin, showed a decay of $41.80 \%$ for the acidic lignin biodegradation sample and a peak of $18.40 \%$ in the alkaline lignin biodegradation sample. This is evidence that the lignin samples experienced two different chemical structure modification processes. These results indirectly reflected the phenomena of partial depolymerization for the acidic biodegradation and the repolymerization for the alkaline biodegradation of lignin. The existence of two possible modification mechanisms altering the chemical structure of lignin are strongly suggested by the chemical structures present for each case in the lignin biodegradation compounds identified by the GC/MS analysis. 
In spite of the two different responses in the optical density, in both cases the statistical analysis showed a significant correlation between the $\mathrm{OD}_{280}$ and the $\mathrm{pH}$. Furthermore, based on the SEM images, referenced at the scale of $1 \mu \mathrm{m}$, the differences in the morphology of the lignin samples were notable. For the acidic biodegradation sample, the lignin blocks were coated on their surfaces by crystalline particles of sizes smaller than $1 \mu \mathrm{m}$. The specific lignin degradation compounds associated with that formation merit further studies.

Based on the results of GC/MS analysis, for acidic biodegradation of lignin, a plethora of compounds with aliphatic chemical structures were found, possibly as a result of intense aromatic ring-opening reactions. The majority of these compounds are alkyl compounds of the type $\mathrm{C}_{3}-\mathrm{C}_{4}$, associated to guaiacyl lignin degradation. This was confirmed by the identification of protocatechuic acid as one of the lignin metabolites (Xu et al., 2019). These compounds have potential applications as renewable substrates for food flavorings, biofuels and adhesives, and copolymers for bioplastics, among others. In contrast, most of the lignin degradation compounds identified in the alkaline biodegradation sample showed a tendency to preserve their aromatic structures. Some of these lignin degradation compounds have potential applications as food flavorings and as medical treatments for inflammations, and tumors.

The high concentration of $1 \mathrm{H}$-indole provided clear evidence that the mild alkaline conditions for lignin biodegradation as a single carbon source represented a stressful environment for the activity of the mutant strain E. coli BL21(Lacc). In connection with this, a phenomenon of increase in the relative abundance of dehydroabietic acid and isovanillyl alcohol was notorious, which ceased until the production of $1 \mathrm{H}$-indole peaked at the seventh day, suggesting the beginning of the stationary phase in the alkaline lignin incubation.

In the case of acidic biodegradation of lignin, reactions similar to aldol condensation may have occurred. For the alkaline biodegradation of lignin, presumably different condensation reactions were more predominant, especially those dependent on relative higher $\mathrm{pH}$ conditions which could activate phenyl groups. It is likely that phenyl intermediates have produced coupling reactions in a small extent of degradation of the aromatic structures, thus, triggering a repolymerization of the lignin backbone, which increased its $\mathrm{Mw}$ value 6.75-fold in relation to the acidic biodegraded sample (Sapapporn et al., 2018). In contrast, for the acidic lignin biodegradation, a repolymerization of the lignin backbone was not indicated, which may have been caused by the methylation of phenolic hydroxyl groups in the aromatic structures of lignin (Kim et al., 2017). Regarding the lignin degradation compounds in the in the acidic and alkaline control samples after 10 days shaking, the generation of those compounds may have been caused by the auto oxidation of reactive monomers, likely related to low molar mass fractions in lignin and mediated by ABTS. For lignin biodegradation by whole bacterial cells, further studies are necessary to shed light on the synergistic reactions between laccase and putative secondary enzymes involved in lignin biodegradation (Li et al., 2014). In the case of the control samples, a better understanding of the mechanisms driving the auto oxidation reactions of the main lignin monomers is required, with vanillin as the main source of the biodegradation/auto oxidation-derived compounds.

Concerning the chemical structure of lignin, the results of FTIR analysis suggest a preponderance of $G$ and $S$ lignins in the samples, which is typical from softwood (Gall et al., 2014). FTIR results did not confirm the existence of $\mathrm{H}$ lignin. The chemical pretreatment of lignin in the acidic biodegradation method produced important modifications. The presence of the $\mathrm{C}=\mathrm{O}$ bond and the $\mathrm{OH}$ functional group, predominantly associated with numerous carboxylic acid molecules were notable. The chemically pretreated alkali lignin with hydrogen peroxide at low $\mathrm{pH}$ values demonstrated its solubility in the liquid phase, without the precipitation of heavy molar mass fractions. This could be explained by the accentuation of the peak at $620 \mathrm{~cm}^{-1}$, which presumably was caused by a SO bond (Nugroho Prasetyo et al., 2010). The strong peak at this wave number could indicate the lack of interference from hydrogen bonds and other non-covalent bonds at very low $\mathrm{pH}$ values, demonstrating that this linkage was not affected by the bacterial activity of the mutant strain E. coli BL21(Lacc). The alkaline biodegraded sample showed the presence of the $\mathrm{N}-\mathrm{H}$ bond (from amine functional groups), confirming the character of the alkalinity of the lignin medium. The FTIR results also displayed further evidence of the existence of the $\mathrm{C}-\mathrm{O}-\mathrm{C}$ bond in the alkaline samples, a key constituent of aryl-ether linkages, viz., $\beta-\mathrm{O}-4$ bonds. This reinforced the idea that in this case the cleavage of such bonds occurred in a lesser extent (Helmich et al., 2016). Furthermore, for

TABLE 5 | Summary of a general comparison between acid versus alkaline biodegradation of lignin by $E$. coli BL21(Lacc).

\begin{tabular}{|c|c|c|}
\hline & Acid biodegradation & $\begin{array}{l}\text { Alkaline } \\
\text { biodegradation }\end{array}$ \\
\hline $\begin{array}{l}\text { Changes in } \\
\mathrm{OD}_{280}\end{array}$ & $\begin{array}{l}\text { Drop in } \mathrm{OD}_{280} \text { values by } 41.8 \% \\
\text { after } 2 \text { days }\end{array}$ & $\begin{array}{l}\mathrm{OD}_{280} \text { values rose } \\
18.4 \% \text { after } 6 \text { days }\end{array}$ \\
\hline $\begin{array}{l}\text { Chemical } \\
\text { pretreatment }\end{array}$ & $\begin{array}{l}140^{\circ} \mathrm{C}, \mathrm{N}_{2}, 400 \mathrm{kPa} \\
141.12 \mathrm{mM} \mathrm{H}_{2} \mathrm{O}_{2}\end{array}$ & $\begin{array}{l}\text { No chemical } \\
\text { pretreatment }\end{array}$ \\
\hline $\begin{array}{l}\text { Initial/final } \mathrm{pH} \\
\text { values }\end{array}$ & $7.0 / 2.53$ & $7.0 / 7.90$ \\
\hline $\begin{array}{l}\text { Lignin } \\
\text { biodegradation } \\
\text { compounds }\end{array}$ & $\begin{array}{l}\text { Crotonic acid, DL-lactic acid, } \\
\text { 3-hydroxybutanoic acid }\end{array}$ & $\begin{array}{l}\text { 2-Phenylethanol, } \\
\text { isovanillyl alcohol, } \\
\text { dehydroabietic acid }\end{array}$ \\
\hline $\mathrm{M}_{\mathrm{w}} / \mathrm{M}_{\mathrm{n}}$ & 4,782/2,054 & $32,325 / 7,095$ \\
\hline Final PDI & 2.32 & 4.55 \\
\hline $\begin{array}{l}\text { Main chemical } \\
\text { structure }\end{array}$ & $\begin{array}{l}\mathrm{OH} \text { and } \mathrm{C}=\mathrm{O} \text { for carboxylic } \\
\text { acids } \mathrm{C}=\mathrm{O} \text { stretch in } \mathrm{GS} \\
\text { lignins, }-\mathrm{C} \equiv \mathrm{N} \text { bond Strong } \\
\text { signal of } \mathrm{S}-\mathrm{O} \text { bond }\end{array}$ & $\begin{array}{l}\mathrm{OH} \text { for alcohols, } \mathrm{C}=\mathrm{C} \\
\text { stretching for aromatic } \\
\text { structures, }-\mathrm{C} \equiv \mathrm{N} \text { bond } \\
\mathrm{N}-\mathrm{H} \text { bonds Stronger } \\
\text { signals of } \mathrm{C}-\mathrm{O}-\mathrm{C} \\
\text { bonds }\end{array}$ \\
\hline
\end{tabular}


the alkaline samples, the wave numbers related to aromatic skeletons/structures were more abundant, suggesting that the preponderant degradation mechanisms were not closely related to ring-opening reactions, as was the case for the acidic biodegradation sample. Table 5 summarizes the most important differences between acidic and alkaline biodegradation of lignin previously discussed.

\section{CONCLUSION}

Partial biodegradation of industrial lignins by microorganisms with ligninolytic enzymes has demonstrated strong potential for producing compounds of interest for industries seeking alternative routes for the production of chemicals. In today's context, the synthesis of many goods still requires the use of non-renewable and toxic substrates, making the supply of more renewable compounds an urgent task. Alkali lignin is one of the industrial lignins that is produced in large amounts and can offer many opportunities due to its low valorization. The ligninolytic action of enzymes, such as bacterial laccase mediated in our case by ABTS, can further oxidize lignin monomers from low molar mass fractions, leading to the generation of many degradation compounds.

Our research strategy consisted of exploring the possibilities of the mutant bacterial strain E. coli BL21(Lacc) to partially degrade alkali lignin at acidic and mild alkaline conditions. In the low $\mathrm{pH}$ range of the spectrum, the mutant strain demonstrated its capacity to oxidize lignin monomers toward an abundant number of short-chain alkyl moieties with potential applications in the food, bio plastics, and adhesives sectors, among others. On the alkaline side of the spectrum, the metabolic activity of the bacterial mutant strain and increase in the relative abundance of compounds namely isovanillyl alcohol and dehydroabietic acid in the context of oxidative stress. Potential applications of these compounds are in the food and pharmacological industries. The possible reaction mechanism was the activation of phenyl radicals in aromatic structures, followed by substitution and repolymerization reactions, which increased its overall molar mass. This upgraded property in the alkaline biodegradation sample could render the building blocks for potential renewable substitutes in the biomaterials area.

By understanding the main reaction mechanisms involved in lignin biodegradation at different values on the $\mathrm{pH}$ spectrum, and by applying the appropriate chemical and biological pretreatment strategies, it is possible to unlock its potential, providing broader alternatives for renewable and bio-derived goods. Future work should tackle these issues.

\section{REFERENCES}

Andrianova, A. A., Yeudakimenka, N. A., Lilak, S. L., Kozliak, E. I., Ugrinov, A., Sibi, M. P., et al. (2018). Size exclusion chromatography of lignin: the mechanistic aspects and elimination of undesired secondary interactions. J. Chromatogr. A 1534, 101-110. doi: 10.1016/j.chroma.2017. 12.051

\section{DATA AVAILABILITY STATEMENT}

The original contributions presented in the study are included in the article/Supplementary Material, further inquiries can be directed to the corresponding author/s.

\section{AUTHOR CONTRIBUTIONS}

GM conception and execution of the experiments, interpretation of the results and, writing and preparation of the manuscript and Supplementary Material. SA assistance in preliminary tests, edition of the figures and, revision and correction of the manuscript. JS and DZ funding of the research work, supervision of the experiments and, revision and corrections of the manuscript. HS assistance in the preparation of the experiments of OD, GC-MS, and SEC analyses. WZ provision of the bacterial mutant strain E. coli BL21(Lacc). RZ assistance in the GC-MS tests arrangements and data analysis. $\mathrm{KH}$ preparation of statistical analysis. All authors read and approved the final manuscript.

\section{FUNDING}

This work was supported by the National Key R\&D Program of China (Grant No. 2018YFE0107100); the National Natural Science Foundation of China (Grant No. 31772529); A Project Funded by the Priority Academic Program Development of Jiangsu Higher Education Institutions, and the Chinese Scholarchip Council, under the number 2016GXYR54.

\section{ACKNOWLEDGMENTS}

We thank Mr. Ricardo Wu from the department of Food Science for providing technical assistance with the GC-MS and FTIR analysis. We thank Mrs. Laura C. Seithers from the College of Education and Human Development, University of Minnesota, United States for English language editing of this manuscript. We also thank Ms. Ting ting Lu from the Biofuels Institute of Jiangsu University for her contributions in the first trial tests of this study.

\section{SUPPLEMENTARY MATERIAL}

The Supplementary Material for this article can be found online at: https://www.frontiersin.org/articles/10.3389/fbioe. 2020.00671/full\#supplementary-material

Bourbonnais, R., and Paice, M. G. (1990). Oxidation of non-phenolic substrates: an expanded role for laccase in lignin biodegradation. FEBS Lett. 267, 99-102. doi: 10.1016/0014-5793(90)80298-w

Bourbonnais, R., Paice, M. G., Freiermuth, B., Bodie, E., and Borneman, S. (1997). Reactivities of various mediators and laccases with kraft pulp and lignin model compounds. Appl. Environ. Microbiol. 63, 4627-4632. doi: 10.1128/aem.63.12. 4627-4632.1997 
Chandra, R., Abhishek, A., and Sankhwar, M. (2011). Bacterial decolorization and detoxification of black liquor from rayon grade pulp manufacturing paper industry and detection of their metabolic products. Bioresour. Technol. 102, 6429-6436. doi: 10.1016/j.biortech.2011.03.048

Chatterjee, S., and Saito, T. (2015). Lignin-derived advanced carbon materials. ChemSusChem 8, 3941-3958. doi: 10.1002/cssc.201500692

Chen, Y. H., Chai, L. Y., Zhu, Y. H., Yang, Z. H., Zheng, Y., and Zhang, H. (2012). Biodegradation of kraft lignin by a bacterial strain Comamonas sp. B9 isolated from eroded bamboo slips. J. Appl. Microbiol. 112, 900-906. doi: 10.1111/j.1365-2672.2012.05275.x

Chen, Z., and Wan, C. (2017). Biological valorization strategies for converting lignin into fuels and chemicals. Ren. Sustain. Energy Rev. 73, 610-621. doi: 10.1016/j.rser.2017.01.166

Cheng, Y., Zhou, Z., Mehmet, A., Sun, D., Zhang, W., and Jiang, J. (2016). Direct liquefaction of alkali lignin in methanol and water mixture for the production of oligomeric phenols and aromatic Ethers. J. Biobased Mater. Bioener. 10, 76-80. doi: 10.1166/jbmb.2016.1572

Christopher, L. P., Yao, B., and Ji, Y. (2014). lignin biodegradation with laccasemediator systems. Front. Energy Res. 2:12. doi: 10.3389/fenrg.2014.00012

Cline, S. P., and Smith, P. M. (2017). Opportunities for lignin valorization: an exploratory process. Energy Sustain. Soc. 7:26.

Constant, S., Wienk, H. L. J., Frissen, A. E., Peinder, P. D., Boelens, R., van Es, D. S., et al. (2016). New insights into the structure and composition of technical lignins: a comparative characterisation study. Green Chem. 18, 2651-2665. doi: $10.1039 / \mathrm{c} 5 \mathrm{gc03043a}$

Doi, Y., Kunioka, M., Nakamura, Y., and Soga, K. (1988). Nuclear magnetic resonance studies on unusual bacterial copolyesters of 3-hydroxybutyrate and 4-hydroxybutyrate. Macromolecules 21, 2722-2727. doi: 10.1021/ma00187a012

Duan, J., Huo, X., Du, W. J., Liang, J. D., Wang, D. Q., and Yang, S. C. (2016). Biodegradation of kraft lignin by a newly isolated anaerobic bacterial strain, Acetoanaerobium sp. WJDL-Y2. Lett. Appl. Microbiol. 62, 55-62. doi: 10.1111/ lam. 12508

El Mansouri, N.-E., and Salvadó, J. (2007). Analytical methods for determining functional groups in various technical lignins. Ind. Crops Prod. 26, 116-124. doi: 10.1016/j.indcrop.2007.02.006

Faix, O. (1991). Classification of Lignins from Different Botanical Origins by FTIR Spectroscopy. Holzforschung Int. J. Biol. Chem. Phys. Technol. Wood 45:21. doi: 10.1515/hfsg.1991.45.s1.21

Gall, D. L., Ralph, J., Donohue, T. J., and Noguera, D. R. (2014). A group of sequence-related sphingomonad enzymes catalyzes cleavage of $\beta$-Aryl Ether linkages in lignin $\beta$-Guaiacyl and $\beta$-Syringyl ether dimers. Environ. Sci. Technol. 48, 12454-12463. doi: 10.1021/es503886d

Gianfreda, L., Xu, F., and Bollag, J.-M. (1999). Laccases: a useful group of oxidoreductive enzymes. Bioremed. J. 3, 1-26. doi: 10.1080/ 10889869991219163

Gillgren, T., Hedenström, M., and Jönsson, L. J. (2017). Comparison of laccasecatalyzed cross-linking of organosolv lignin and lignosulfonates. Int. J. Biol. Macromol. 105, 438-446. doi: 10.1016/j.ijbiomac.2017.07.061

Gioia, C., Banella, M. B., Totaro, G., Vannini, M., Marchese, P., Colonna, M., et al. (2018). Biobased vanillic acid and ricinoleic acid: building blocks for fully renewable copolyesters. J. Ren. Mater. 6, 126-135. doi: 10.7569/jrm.2017. 634191

González, M. A. (2015). Aromatic abietane diterpenoids: their biological activity and synthesis. Nat. Prod. Rep. 32, 684-704. doi: 10.1039/c4np00110a

Gordobil, O., Moriana, R., Zhang, L., Labidi, J., and Sevastyanova, O. (2016). Assesment of technical lignins for uses in biofuels and biomaterials: structurerelated properties, proximate analysis and chemical modification. Ind. Crops Prod. 83, 155-165. doi: 10.1016/j.indcrop.2015.12.048

Hack, E., Hümmer, D., and Franzreb, M. (2019). Concentration of crotonic acid using capacitive deionization technology. Separat. Purificat. Technol. 209, 658665. doi: 10.1016/j.seppur.2018.08.049

Hallac, B. B., and Ragauskas, A. J. (2014). "CHAPTER 4 lignin modification to reduce the recalcitrance of biomass processing," in Biological Conversion of Biomass for Fuels and Chemicals: Explorations From Natural Utilization Systems, (Cambridge, UK: Royal Society of Chemistry), 37-52. doi: 10.1039/ 9781849734738-00037

Helmich, K. E., Pereira, J. H., Gall, D. L., Heins, R. A., McAndrew, R. P., Bingman, C., et al. (2016). Structural basis of stereospecificity in the bacterial enzymatic cleavage of $\beta$-Aryl ether bonds in lignin. J. Biol. Chem. 291, 5234-5246. doi: 10.1074/jbc.m115.694307

Janßen, H. J., and Steinbüchel, A. (2014). Fatty acid synthesis in Escherichia coli and its applications towards the production of fatty acid based biofuels. Biotechnolo. Biofuels 7:7. doi: 10.1186/1754-6834-7-7

Kim, J., Kim, J., Um, Y., and Kim, K. H. (2019). Intracellular metabolite profiling and the evaluation of metabolite extraction solvents for Clostridium carboxidivorans fermenting carbon monoxide. Proc. Biochem. 89, 20-28. doi: 10.1016/j.procbio.2019.10.012

Kim, K. H., Dutta, T., Walter, E. D., Isern, N. G., Cort, J. R., Simmons, B. A., et al. (2017). Chemoselective methylation of phenolic Hydroxyl group prevents quinone methide formation and repolymerization during lignin depolymerization. ACS Sustain. Chem. Eng. 5, 3913-3919. doi: 10.1021/ acssuschemeng.6b03102

Kohlstedt, M., Starck, S., Barton, N., Stolzenberger, J., Selzer, M., Mehlmann, K., et al. (2018). From lignin to nylon: cascaded chemical and biochemical conversion using metabolically engineered Pseudomonas putida. Metab. Eng. 47, 279-293. doi: 10.1016/j.ymben.2018.03.003

Kosa, M., and Ragauskas, A. J. (2013). Lignin to lipid bioconversion by oleaginous rhodococci. Green Chem. 15, 2070-2074.

Lee, H. H., Molla, M. N., Cantor, C. R., and Collins, J. J. (2010). Bacterial charity work leads to population-wide resistance. Nature 467, 82-85. doi: 10.1038/ nature09354

Li, Z., Nimtz, M., and Rinas, U. (2014). The metabolic potential of Escherichia coli BL21 in defined and rich medium. Microb. Cell Fact. 13, 45. doi: 10.1186/14752859-13-45

Margot, J., Bennati-Granier, C., Maillard, J., Blánquez, P., Barry, D. A., and Holliger, C. (2013). Bacterial versus fungal laccase: potential for micropollutant degradation. $A M B$ Express 3:63.

Moya, R., Saastamoinen, P., Hernández, M., Suurnäkki, A., Arias, E., and Mattinen, M.-L. (2011). Reactivity of bacterial and fungal laccases with lignin under alkaline conditions. Bioresour. Technol. 102, 10006-10012.

Nugroho Prasetyo, E., Kudanga, T., Østergaard, L., Rencoret, J., Gutiérrez, A., del Río, J. C., et al. (2010). Polymerization of lignosulfonates by the laccase-HBT (1hydroxybenzotriazole) system improves dispersibility. Bioresour. Technol. 101, 5054-5062.

Perez, J. M., Kontur, W. S., Alherech, M., Coplien, J., Karlen, S. D., Stahl, S. S., et al. (2019). Funneling aromatic products of chemically depolymerized lignin into 2-pyrone-4-6-dicarboxylic acid with Novosphingobium aromaticivorans. Green Chem. 21, 1340-1350.

Rajan, R., Skrifvars, M., and Järvelä, P. (2014). "Lactic Acid Polymers: Synthesis, Properties, and Applications," in Handbook of Green Materials, eds K. Oksman, A. P. Mathew, A. Bismarck, O. Rojas, and M. Sainpp (Singapore: World Scientific), 49-65.

Reyes-Rivera, J., and Terrazas, T. (2017). Lignin Analysis by HPLC and FTIR. Methods Mol. Biol. 1544, 193-211.

Ruijssenaars, H. J., and Hartmans, S. (2004). A cloned Bacillus halodurans multicopper oxidase exhibiting alkaline laccase activity. Appl. Microbiol. Biotechnol. 65, 177-182.

Saito, T., Perkins, J. H., Jackson, D. C., Trammel, N. E., Hunt, M. A., and Naskar, A. K. (2013). Development of lignin-based polyurethane thermoplastics. RSC Adv. 3, 21832-21840.

Sapapporn, N., Chaijamrus, S., Chatdumrong, W., and Tochampa, W. (2018). Degradation and polymerization of black liquor lignin using Bacillus sp. isolated from a pulp mill. Bioresources 14, 1049-1076.

Sendovski, M., Nir, N., and Fishman, A. (2010). Bioproduction of 2-phenylethanol in a biphasic ionic liquid aqueous system. J. Agric. Food Chem. 58, 2260-2265.

Sharma, R. K., Mukhopadhyay, D., and Gupta, P. (2019). Microbial fuel cellmediated lignin depolymerization: a sustainable approach. J. Chem. Technol. Biotechnol. 94, 927-932.

Shi, Y., Yan, X., Li, Q., Wang, X., Liu, M., Xie, S., et al. (2017). Directed bioconversion of Kraft lignin to polyhydroxyalkanoate by Cupriavidus basilensis B-8 without any pretreatment. Process Biochem. 52, $238-242$.

Shinoda, E., Takahashi, K., Abe, N., Kamimura, N., Sonoki, T., and Masai, E. (2019). Isolation of a novel platform bacterium for lignin valorization and its application in glucose-free cis,cis-muconate production. J. Ind. Microbiol. Biotechnol. 46, 1071-1080. 
Stefanska, J., and Pawliczak, R. (2008). Apocynin: molecular aptitudes. Mediators Inflamm. 2008, 106507-106507.

Suman, S. K., Dhawaria, M., Tripathi, D., Raturi, V., Adhikari, D. K., and Kanaujia, P. K. (2016). Investigation of lignin biodegradation by Trabulsiella sp. isolated from termite gut. Int. Biodeteriorat. Biodegradat. 112, 12-17.

Sun, J.-X., Sun, X.-F., Sun, R.-C., Fowler, P., and Baird, M. S. (2003). Inhomogeneities in the chemical structure of sugarcane bagasse lignin. J. Agric. Food Chem. 51, 6719-6725.

Vahermo, M., Krogerus, S., Nasereddin, A., Kaiser, M., Brun, R., Jaffe, C. L., et al. (2016). Antiprotozoal activity of dehydroabietic acid derivatives against Leishmania donovani and Trypanosoma cruzi. MedChem Comm 7, 457-463.

Van den Bosch, S., Koelewijn, S. F., Renders, T., Van den Bossche, G., Vangeel, T., Schutyser, W., et al. (2018). Catalytic strategies towards lignin-derived chemicals. Top. in Curr. Chem. 376:36.

Vinardell, M. P., and Mitjans, M. (2017). Lignins and their derivatives with beneficial effects on human health. Int. J. Mol. Sci. 18:1219.

Wade, L. G. J. (2013). Organic Chemistry, 8th Edn. London: Pearson.

Xi, X., Hu, S., Zhou, Z., Liu, X., Tang, J., and Shen, Y. (2016). Dendrimers with the protocatechuic acid building block for anticancer drug delivery. J. Mater. Chem. B 4, 5236-5245.

Xu, F. (1997). Effects of redox potential and hydroxide inhibition on the ph activity profile of fungal laccases. J. Biol. Chem. 272, 924-928.

Xu, Z., Lei, P., Zhai, R., Wen, Z., and Jin, M. (2019). Recent advances in lignin valorization with bacterial cultures: microorganisms, metabolic pathways, and bio-products. Biotechnol. Biofuels 12, 32-32.

Yang, H., Yan, R., Chen, H., Lee, D. H., and Zheng, C. (2007). Characteristics of hemicellulose, cellulose and lignin pyrolysis. Fuel 86, 1781-1788.

Yang, S., Yu, H., You, Y., Li, X., and Jiang, J. (2018). Effective lactic acid production from waste paper using Streptococcus thermophilus at low enzyme loading assisted by Gleditsia saponin. Carbohydrate Polym. 200, 122-127.
Yang, Y., Song, W.-Y., Hur, H.-G., Kim, T.-Y., and Ghatge, S. (2019). Thermoalkaliphilic laccase treatment for enhanced production of highvalue benzaldehyde chemicals from lignin. Int. J. Biol. Macromol. 124, 200-208.

Yu, H., Hou, J., Yu, S., Liu, S., Li, L., Wu, Q., et al. (2019). Comprehensive understanding of the non-productive adsorption of cellulolytic enzymes onto lignins isolated from furfural residues. Cellulose 26, 3111-3125.

Zhu, D., Si, H., Zhang, P., Geng, A., Zhang, W., Yang, B., et al. (2018). Genomics and biochemistry investigation on the metabolic pathway of milled wood and alkali lignin-derived aromatic metabolites of Comamonas serinivorans SP-35. Biotechnol. Biofuels 11:338.

Zhu, D., Tanabe, S.-H., Xie, C., Honda, D., Sun, J., and Ai, L. (2014). Bacillus ligniniphilus sp. nov., an alkaliphilic and halotolerant bacterium isolated from sediments of the South China Sea. Int. J. Syst. Evol. Microbiol. 64, 1712-1717.

Zhu, D., Zhang, P., Xie, C., Zhang, W., Sun, J., Qian, W.-J., et al. (2017). Biodegradation of alkaline lignin by Bacillus ligniniphilus L1. Biotechnol. Biofuels 10:4.

Conflict of Interest: The authors declare that the research was conducted in the absence of any commercial or financial relationships that could be construed as a potential conflict of interest.

Copyright (๐ 2020 Murillo Morales, Ali, Si, Zhang, Zhang, Hosseini, Sun and Zhu. This is an open-access article distributed under the terms of the Creative Commons Attribution License (CC BY). The use, distribution or reproduction in other forums is permitted, provided the original author $(s)$ and the copyright owner(s) are credited and that the original publication in this journal is cited, in accordance with accepted academic practice. No use, distribution or reproduction is permitted which does not comply with these terms. 